\title{
Dark Triad Personality Traits and Selective Hedging
}

\author{
Matthias Pelster $^{1}$ (D) Annette Hofmann ${ }^{2} \cdot$ Nina Klocke $^{1} \cdot$ Sonja Warkulat ${ }^{1}$
}

Received: 29 January 2021 / Accepted: 25 October 2021 / Published online: 9 November 2021

(c) The Author(s) 2021

\begin{abstract}
We study the relationship between risk managers' dark triad personality traits (Machiavellianism, narcissism, and psychopathy) and their selective hedging activities. Using a primary survey of 412 professional risk managers, we find that managers with dark personality traits are more likely to engage in selective hedging than those without. This effect is particularly pronounced for older, male, and less experienced risk managers. The effect is also stronger in smaller firms, less centralized risk management departments, and family-owned firms.
\end{abstract}

Keywords Managers $\cdot$ Personality traits $\cdot$ Corporate risk management $\cdot$ Selective hedging

JEL Classification G30 · G34 · G39

[...] the most significant risk management failures in recent history have their roots in psychology, and [...] the practice of risk management can be improved by incorporating an explicit psychological dimension. Shefrin (2016)

\section{Introduction}

The main goal of financial risk management is to stabilize cash flows, eliminate specific sources of volatility, reduce the risk of losing money because of market uncertainty, and reduce the probability of entering distress (Mian, 1996; Faulkender, 2005; Stulz, 1996, 2013). In contrast to passive hedging, selective hedging refers to managers actively varying the size of their hedge ratios and the timing of their derivatives transactions based on their market views,

Matthias Pelster

matthias.pelster@upb.de

Annette Hofmann

hofmanna@stjohns.edu

1 Center for Risk Management, Paderborn University, Warburger Str. 100, 33098 Paderborn, Germany

2 Maurice R. Greenberg School of Risk Management, Insurance and Actuarial Science, St. John's University, 101 Astor Place, New York, NY 10003, USA personal preferences, attitudes, or skills (Stulz, 1996; Brown et al., 2006; Adam et al., 2015, 2017). By doing so, managers increase the risk exposure of firms, the firms' probabilities of bankruptcy, and-ultimately - the firms' future stock return volatility (Adam et al., 2017; Stulz 1996). As such, selective hedging stands in contrast to corporate risk management policies from textbook hedging (Beber \& Fabbri, 2012).

Prior studies provide global evidence that firms adjust their hedge ratios and regularly speculate within the context of their hedging programs (Adam \& Fernando, 2006; Tufano, 1996). For example, Beber and Fabbri (2012) find that $63 \%$ of firms in their sample change their derivative position at least by $30 \%$ every year, which is consistent with managers adjusting derivative holdings over time according to active views, but "hard to reconcile with derivatives being exclusively managed according to an optimal hedging policy" (p. 1066).

A large body of literature shows that the additional risk in selective hedging does not increase shareholders' returns (Beber \& Fabbri, 2012; Brown et al., 2006). Adam et al. (2017) document that the extent of selective hedging is positively correlated with a firm's future stock return volatility, supporting the homonymous suggestion by Stulz (1996). In fact, firms that speculate the most feature the highest probabilities of bankruptcy (Adam et al., 2017).

Companies incurring major losses from selective hedging highlight its potentially devastating consequences. For 
example, Japan's leading oil refiner and distributor, Showa Shell Sekiyu, half-owned by the Royal Dutch/Shell Group, reported in February 1993 that it lost approximately $\$ 1$ billion-more than $80 \%$ of its shareholder equity at the time-because of risk managers' unauthorized incorporation of their market views in hedging decisions, speculating that the US dollar would rise against the yen (Ipsen, 1993). Similarly, Chesapeake's reported selective hedging losses exceeded \$750 million in 2012 from hedging decisions that were essentially speculative (Adam et al., 2017). Against this backdrop, "the widespread practice of managers speculating by incorporating their market views into firms' hedging programs ("selective hedging") remains a puzzle" (Adam et al., 2017).

Liu et al. (2020) note that "people hope and expect that appointees to high-ranking positions will use their authority wisely and for the betterment of their organizations" (p. 745). Based on this principle and considering that the primary task of risk managers is to reduce volatility, one would expect them not to engage in selective hedging and, by doing so, increase the risk exposure of the firm. Given the potentially severe financial losses that might result in serious consequences for investors, employees, and the company's reputation, the additional risk-taking of risk managers is ethically at least debatable.

This paper studies how risk managers' personality traits can explain selective hedging and shows that dark personality traits increase managers' propensity to engage in selective hedging. Our hypothesis is based on the notion that dark personality traits are associated with increased sensationseeking and risky behaviors (Crysel et al., 2013). Engaging in selective hedging activities satisfies the sensation-seeking need of managers with pronounced dark personality traits. It may also be a good match for other typical behavioral patterns of people with pronounced Machiavellistic, narcissistic, or psychopathic personality traits. As noted by Bajo et al. (2021), "derivative usage offers the narcissistic manager a convenient stage for bold and decisive action that generates a continuous supply of attention."

The upper echelons theory establishes a general link between managerial characteristics and firm outcomes (Hambrick \& Mason, 1984; Hambrick, 2007). Senior managers influence firm outcomes both directly through their immediate decisions and indirectly through their guiding example, behavior, and values (Berson et al., 2008). Middle managers with decision-making authority also serve as important interfaces by shaping strategic decisions and firm outcomes (Balogun \& Johnson, 2004). According to Wooldridge et al. (2008), "middle managers are central to explaining key organizational outcomes." Given that managers exert a strong influence on corporate decisions, we study the impact of dark personality traits on firms' selective hedging activities.
We build on the psychological literature to study the effects of (dark) managerial personality traits on corporate hedging. The most prominent negative personality traits are Machiavellianism, narcissism, and psychopathy. Due to their significant overlap, they are together referred to as the dark triad of personality (Paulhus \& Williams, 2002). Affecting different parts of the unethical decision-making process, the elements of the dark triad nevertheless act in concert as powerful psychological antecedents to unethical behaviors (Harrison et al. 2018). Dark triad traits predict individuals' propensity to take financial, investment, and gambling risks (Sekścińska \& Rudzinska-Wojciechowska, 2020). Dark personality traits also predict various (workplace) behaviors (Neo et al. 2018) and may inflict financial damage on the firm (see, e.g.,Babiak \& Hare, 2006, for the case of corporate psychopathy). Dark triad personality features have been associated with a series of undesirable (firm) outcomes, such as extreme and fluctuating organizational performance (Chatterjee \& Hambrick, 2007) or reduced investment performance (ten Brinke et al., 2018).

Our survey-based approach allows us to access managers' personality traits and their hedging activities at the same time. We use the "dirty dozen scale" to elicit managers' dark triad personality traits (see also Jonason \& Webster, 2010). We follow Mutschmann et al. (2021) and obfuscate the questions within several other uncontroversial questions to ensure that participants do not immediately realize that they are describing potentially negatively perceived personality traits. We carefully control for other potential drivers of selective hedging, such as the manager's age, overconfidence, and risk preferences. Additionally, we study the moderating influence of the firm's ownership structure and managerial discretion.

Dark personality traits are prevalent among the overall population (Boddy, 2017; Caponecchia et al., 2012), and even more so in the corporate environment (Babiak et al., 2010). Various characteristics of a person with dark personality traits seem to be advantageous when rising to leadership positions in organizations (Babiak \& Hare, 2006; Rovelli \& Curnis, 2020). Organizations might even hire managers with dark personality traits because their willingness to push ethical boundaries aligns with organizational objectives (Harris et al., 2021).

We contribute to the literature in three important ways. First, we link findings from personality psychology to the corporate risk management literature by analyzing whether dark personality traits influence corporate risk management. Doing so, we extend the existing knowledge on the motivations and drivers of selective hedging. Second, we analyze whether the organizational context can function as a moderator of the influence of personality traits on corporate hedging activities. Important practical implications arise from understanding the conditions under which the 
influence of personality traits on selective hedging is most pronounced. Third, we contribute to personality theory in the management context. While a large part of the literature on managerial personality traits focuses on narcissism (see, e.g., Petrenko et al., 2016) to exploit several readily available proxies for this personality trait (e.g., signature size, the use of first-person pronouns, or the size of the manager's picture in annual reports), we study the influence of dark personality traits in general. By doing so, we also address concerns regarding the validity of these proxies for narcissism (Carey et al., 2015).

\section{Related Literature and Hypotheses}

\section{Corporate Hedging and Selective Hedging}

Traditional corporate risk management theory suggests that passively matching one risk exposure with an opposing one creates value for shareholders (see, e.g.,Geyer-Klingeberg et al., 2020, for a recent meta-analysis). In particular, derivatives allow firms to stabilize their cash flows by eliminating specific sources of volatility (Moore et al., 2000). While the theory does not suggest that companies should hedge their entire risk exposure and create a hedge ratio of $100 \%$, it argues that firms should determine their optimal hedging policies based on their preferences and passively adhere to them without actively attempting to time hedging decisions based on their market views. For instance, companies might decide to passively hedge $50 \%$ to prevent financial distress and still be in line with traditional academic theory (Stulz, 1996). In a similar fashion, a passive risk management strategy that is designed to protect the firm against costly lowertail outcomes is in line with theoretical recommendations from a corporate value-adding perspective. Additionally, this traditional notion of risk management does not hinge on the concept that hedging transactions have zero net present value-that hedging is costless. ${ }^{1}$

Corporate risk management adds value to the firm by alleviating market imperfections (Adam \& Fernando, 2006). Hedging affects firm values by reducing the probability of financial distress and expected bankruptcy costs, underinvestment risk, expected tax liabilities, agency costs, and information asymmetries (see, e.g.,Campello et al., 2011; Carter et al., 2006; Froot et al., 1993). Estimating the increase in firm value, Geyer-Klingeberg et al. (2020) find that foreign currency hedgers realize a firm value hedging premium of $1.8 \%$. Firms that have access to newly created

\footnotetext{
${ }^{1}$ In fact, Adam and Fernando (2006) show that this assumption can be violated for extended periods.
}

hedging opportunities also experience up to a $40 \%$ decline in the variance of their stock returns (Biguri et al., 2018).

However, this passive risk avoidance notion of hedging is deficient in explaining hedging behavior in practice (Adam et al., 2015; Haushalter, 2000). Survey studies of corporate risk management have shown considerable (time) variation in managerial practice because risk managers seem to incorporate their market views and actively vary their hedge ratios (Adam and Fernando 2006; Brown et al. 2006). In contrast to the theoretical notion discussed above, selective hedging increases the risk exposure of firms (Adam et al. 2017).

A theoretical attempt to explain selective hedging that is in line with a shareholder value-adding perspective comes from Stulz (1996), who argues that some firms might have a comparative advantage in bearing certain financial risks, for example, inside information. Although it is unclear which firms might have an informational advantage, larger firms have higher potential to acquire valuable information than smaller firms because they can hire better analysts and have a more expansive market footprint (Stulz, 1996). Nevertheless, the major risk associated with selective hedging is that the firm's information might not in fact be better than the market's and managers acting on their market views might in fact destroy value (Brown et al. 2006). According to Stulz (1996), "the lesson of market efficiency for corporate risk managers is that the attempt to earn higher returns in most financial markets generally means bearing large (and unfamiliar) risks." Even if the firm has comparative advantages, the possibility always exists that the firm will experience significant losses from selective hedging.

Thus, not surprisingly, cash flow gains from selective hedging appear to be small at best, and it does not provide meaningful economic gains (Adam \& Fernando, 2006; Brown et al. 2006). If anything, passive hedgers appear to have outperformed selective hedgers (see, e.g., Beber \& Fabbri, 2012). Consistent with the homonymous notion of Stulz (1996), Adam et al. (2017) even document that the extent of selective hedging is positively correlated with a firm's future stock return volatility and that firms that speculate the most feature the highest probabilities of bankruptcy. Overall, the evidence does not support the notion that selective hedging increases firm value.

Several recent studies attempt to explain the heterogeneity in the corporate use of derivatives. For example, a firm's ownership structure (Pennings and Garcia 2004) or managerial power and inside ownership (Jankensgård, 2019) might explain some of this heterogeneity. Moreover, selective hedging is more prevalent among financially constrained firms, but not related to managerial compensation (Adam et al., 2017; Croci et al., 2017).

Another approach to explain the differences in the corporate use of derivatives is to take a closer look at managers. Risk managers' personal characteristics have been shown 
to exhibit strong explanatory power over firm and industry characteristics (Beber \& Fabbri, 2012). Pennings and Garcia (2004) highlight that factors such as risk perception and individual risk preferences explain variations in derivatives usage, whereas Croci et al. (2017) report that firms' hedging practices vary with CEO age. Beber and Fabbri (2012) find that younger, MBA-trained, and less experienced managers exhibit higher variability in notional amounts of hedging dimensions. Adam et al. (2015) propose managerial behavioral biases, in particular overconfidence, as an explanation for selective hedging. Firms hedge more selectively following past gains, which Adam et al. (2015) attribute to increased confidence levels that lead managers to believe they have superior information or ability when they do not. Most closely related to our study, Bajo et al. (2021) investigate the relationship between narcissism and selective hedging and find that narcissistic managers engage more in selective hedging activities.

At the end of the day, many observations and research findings around the practice of selective hedging remain puzzling (Adam et al., 2017). We attempt to help solve this puzzle and investigate the extent to which (dark) personality traits contribute to selective hedging.

\section{Dark Triad Personality Traits}

Personality traits make up who an individual is as a person, defining one's personal values and preferences (Parks-Leduc et al., 2015). The dark triad includes the most prominent negative personality traits: Machiavellianism, narcissism, and psychopathy (Paulhus \& Williams, 2002).

Individuals who score high on the Machiavellianism scale are, on average, more self-interested and opportunistic than those who do not (Gunnthorsdottir et al., 2002). They exhibit less guilt (Murphy, 2012) and have been reported to be more likely to cheat, manipulate others for their own gain, and believe that manipulation is an important key to success (Paulhus \& Jones, 2015). Moreover, Machiavellianism is often accompanied by a lack of empathy and a focus on pursuing one's own goals at the expense of others (LeBreton et al. 2018). Individuals with pronounced Machiavellianism have a view of morality that offers a greater acceptance of behaviors that are normally be described as immoral or unethical (LeBreton et al., 2018).

Individuals with narcissistic traits are known for their continuous need for attention and admiration from others as well as the continuous reinforcement of their ego (Vazire \& Funder, 2006). As a result, their behavior is directed toward gaining status and esteem (Campbell et al., 2004). Highly narcissistic individuals feel a need to undertake large-stakes initiatives to reinforce their ego (Chatterjee \& Hambrick, 2007). Narcissists are characterized by thinking that they are more intelligent than they actually are, and by having a need to feel superior to others (Gabriel et al., 1994). In addition, they display high levels of impulsivity (Vazire \& Funder, 2006). Similar to individuals with pronounced Machiavellianism, narcissists are associated with cheating and unethical behavior (Menon \& Sharland, 2011). They are also more likely to show a propensity for engaging in exploitative acts or behaviors and simultaneously lack empathy with a tendency toward callousness (LeBreton et al., 2018). Finally, Vogel (2006) argues that the typical narcissist is unfazed by setbacks and feels neither regret nor remorse.

Individuals with psychopathic traits exhibit a significant lack of consciousness and feelings for others. They experience low empathy and remorse (Babiak \& Hare, 2006) and do as they please without any feeling of guilt (Hare, 1999). Individuals with psychopathic traits are characterized as reckless, selfish, and aggressive (Patrick, 2007). Williams et al. (2007) note that psychopaths pursue an irresponsible lifestyle and counterproductive behavior.

All three personality traits of the dark triad are associated with an increase in excitement seeking and risk-taking (Crysel et al., 2013). Individuals with Machiavellian (Rim, 1966), narcissistic (Campbell et al., 2004), and psychopathic (Jones, 2014) traits generally take more risks than those without these traits. Sekścińska and RudzinskaWojciechowska (2020) find that narcissism and psychopathy also predict individuals' general propensity for financial risk-taking. Individuals with narcissistic traits cannot stand boredom because it creates a mismatch between their high inner ambitions and external goals (Wink \& Donahue, 1997). As a result, they tend to engage more in "sensationseeking" (Emmons, 1981). Similarly, psychopaths have also been reported to more heavily engage in sensation-seeking (Zuckerman, 1979).

Studies on the composite dark triad of personality traits have associated individuals with a high dark triad score with emotional coldness, unethical decision making, a lack of guilt and remorse, and a sense of superiority (Babiak \& Hare, 2006; Paulhus \& Williams, 2002; Stevens et al., 2012).

\section{Dark Triad Personality Traits in the Context of the Firm}

Dark personality traits might be especially pronounced among corporate executives (Furtner et al., 2017). In fact, Kets de Vries (2004) notes that narcissism is "at the heart of leadership" and that rising to the top of an organization might be facilitated by a dose of narcissism (p. 188). Dark triad personalities can be found among leaders because of their strong need for power and their social dominance orientation (Furtner et al., 2017). Furthermore, individuals with psychopathic traits are good at strategic thinking and tend to be innovative (Babiak \& Hare, 2006). Consequently, the 
impact of dark personality traits has also been studied in an organizational context.

Among others, the literature has studied the volatility of organizational performance (Chatterjee \& Hambrick, 2007), the M\&A process (Aktas et al., 2016), accounting choices and fraudulent reporting (Mutschmann et al., 2021), corporate sustainability (Pelster \& Schaltegger, 2021), and risk management decisions (Bajo et al., 2021) in connection with managerial personality traits. Managerial narcissism has also been associated with less effective monitoring (Chatterjee \& Pollock, 2017). Overall, psychopathic characteristics in firms' top management teams reduce future shareholder wealth (Omar et al., 2019).

Chatterjee and Hambrick (2007) document that CEOs with narcissistic personality traits create extreme and fluctuating organizational performance. Despite the more volatile performance, however, firms with narcissistic CEOs realize similar performance compared to firms with non-narcissistic CEOs, on average. Similarly, Chatterjee and Hambrick (2011) evaluate the impact of narcissism on CEOs' risktaking and find that highly narcissistic CEOs are much less responsive to recent objective performance than their less narcissistic peers. In contrast to these findings, ten Brinke et al. (2018) find that hedge fund managers with more psychopathic tendencies produced lower absolute returns than their less psychopathic peers and that managers with more narcissistic traits produced decreased risk-adjusted returns.

Individuals who exhibit higher Machiavellianism are more likely to engage in fraudulent financial reporting and feel significantly less guilt than others who misreport (Murphy, 2012). Related, Rijsenbilt and Commandeur (2013) find that Machiavellians seem to be more willing to tamper with financial accounts or engage in fraudulent behavior in an effort to preserve their positive self-image. Managers with greater narcissistic personality tendencies are more likely to inflate reported earnings when there are positive social status implications, such as praise, acclaim, and affirmation (Hobson \& Resutek, 2008).

Studying corporate risk management, Bajo et al. (2021) argue that even in the absence of specific beliefs about markets, narcissistic managers might be attracted to derivative usage as a way to enhance their self-image. Making bets using derivatives draws attention and staves off boredom at the same time and might help sustain a perception of the manager as bold and decisive.

In conclusion, a large part of the literature that relates dark personality traits to organizational outcomes focuses on narcissism as a single construct. Much less thought has been given to Machiavellianism, psychopathy, and the dark triad composite scale, which is surprising considering that, for example, Machiavellianism, narcissism, and psychopathy might act together to explain certain behaviors (Harrison et al., 2018). Thus, we argue that the composite dark triad trait might incorporate the various dimensions of a dark personality that relate to selective hedging activities. In addition, Jonason and Webster (2010) note that the individual scales for Machiavellianism, narcissism, and psychopathy are associated with distinctive response biases. Hence, measuring all three traits simultaneously increases internal consistency.

\section{Hypotheses}

Based on the above insights, we hypothesize that risk managers who score high on the dark triad personality scale engage more heavily in selective hedging activities than other risk managers. Selective hedging provides these managers with benefits that cater to their personal preferences. It provides them with additional excitement and satisfies their "thirst for risk." Moreover, selective hedging provides the potential for large additional financial gains that will be attributed to the manager's skill, satisfying the need for attention and status. Finally, managers who score high on the dark triad scale are not affected by the negative outcomes of their speculative behavior because they do not experience feelings of guilt and are likely able to allocate the blame to someone else. As a result, our main hypothesis is as follows:

H1: Managers who score high on the dark triad personality scale engage more heavily in selective hedging activities.

Next, we analyze the cross-sectional differences in the connection between dark triad personality traits and selective hedging along several dimensions. Considering that several demographic characteristics, such as age and gender, are known to be important determinants of general risk-taking behavior (see, e.g.,Halek and Eisenhauer 2001; He et al. 2008) and seem to impact managers' hedging practices (Croci et al., 2017; Beber \& Fabbri, 2012), age and gender might also moderate the relationship between dark triad personality traits and selective hedging activities. Because female and older decision makers are reported to be more risk averse than male and younger decision makers, we hypothesize

H2: The influence of managers' dark personality traits on their selective hedging activities is greater for male and younger managers.

In a similar vein, experience has been documented to have important effects on behavioral biases (Feng \& Seasholes, 2005) and managers' hedging preferences (Beber \& Fabbri, 2012). In particular, experience has been shown to mitigate the impact of behavioral biases on decision making (Feng $\&$ Seasholes, 2005). We hypothesize 
H3: The influence of managers' dark personality traits on their selective hedging activities is stronger for less experienced managers.

At the same time, managers' education influences their hedging decisions (Beber \& Fabbri, 2012). In particular, a higher educational background could provide a manager with superior information and a higher (perceived) ability to time the market and forecast future market developments. People with a superior educational background might be more risk tolerant or even (over)confident as a result of their (perceived) superior training. In fact, managers with higher educational degrees follow more aggressive strategies (Bertrand \& Schoar, 2003). Thus, it is reasonable to assume that education and (perceived) expertise might also moderate the relationship between dark triad personality traits and selective hedging. We hypothesize

H4: The influence of managers' dark personality traits on their selective hedging activities is greater for highly educated managers.

Risk managers with dark personality traits need to have a platform to receive attention and admiration for their selective hedging activities. These managers need to be able to regularly report to their supervisors on their hedging activities. Otherwise, risk managers will not have access to external admiration, to a large extent. Consequently, a reduced reporting frequency undermines the benefits of these managers from engaging in selective hedging. Hence, we hypothesize the following:

H5: The influence of managers' dark personality traits on their selective hedging activities is stronger for managers who report on their hedging activities more frequently.

Risk managers might have different perceptions about what constitutes successful risk management. Some risk managers might perceive little variation in firms' cash flows as an indication of successful risk management - in line with traditional theories of corporate risk management. Others, however, might perceive the creation of financial gains with their derivatives usage as an indication of successful risk management. For managers with pronounced dark personality traits to feel admired for their financial gains, these managers first need to perceive generating financial gains as an indication of successful risk management. Thus, risk managers who feel that only little cash flow variation is a sign of successful risk management will not feel excited about financial gains. We hypothesize

H6: The influence of managers' dark personality traits on their selective hedging activities is greater for managers who perceive financial gains as an indication of successful risk management.

The organizational context is important for managerial interpretations (Sharma, 2000). Firms that have established routines and structures with respect to corporate hedging decisions leave less scope for managerial discretion. In addition, empirical findings indicate that selective hedging is related to managerial power (Jankensgård, 2019). Therefore, organizational factors might also moderate the impact of managers' personality traits on their selective hedging decisions. Managers' personality traits might influence their risk management activities through their opportunity to exercise discretion (Finkelstein \& Hambrick, 1990; Finkelstein \& Boyd, 1998). Thus, we hypothesize

H7: The influence of managers' dark personality traits on their selective hedging activities increases in their managerial discretion.

\section{Methodology and Data}

An online survey allows us to gather data on the personality traits of risk managers and their preferred hedging activities at the same time, which would not be possible using large archival data sources (see, e.g., Graham et al., 2013). Using a self-reported measure provides a valid proxy for managers' personality traits. In fact, Cragun et al. (2020) emphasize in their meta-analysis that a psychometric self-report is the first choice for researchers to study managers' personality traits, while Graham et al. (2013) argue that inferring managerial attitudes from observed actions in archival datasets raises questions about the validity of the action as a broad-based proxy. Moreover, such samples are limited to a few managers for whom such actions are observable (Graham et al., 2013).

\section{Data Collection}

The survey targets high-ranking professionals responsible for the corporate hedging decisions of their organization. We commissioned QuestionPro-one of the largest providers of online panels with a database of more than 22 million potential respondents - to carry out the actual questioning of the respondents. QuestionPro's business online panel consists primarily of business decision makers. During the recruiting process, individuals are asked to indicate several characteristics about themselves, allowing researchers to profile respondents based on, for example, the industry or the department of their occupation. QuestionPro provides respondents a strong assurance of anonymity, which may improve the response rate and quality of the data collected (Durant et al., 2002; Pearlin, 1961) and is compliant with 
general data protection regulations. Thus, making use of this database allows us to obtain a high-quality sample. The survey was executed in English via the QuestionPro survey platform.

The invitation to the survey was sent to 1220 professionals in September 2020. We specifically targeted individuals who had previously indicated that they hold a high-ranking position (e.g., EVP, SVP, AVP, Director or Group Manager, Senior Manager) with decision-making authority in the financial department of their organization. We targeted individuals from financial departments because previous research indicates that the risk management function is commonly anchored in this division (Aabo et al., 2012). We screened individuals for whether their original indications are still up to date. In addition, respondents had to reply "yes" to two qualifying questions to be included in our survey. The organization for which they worked had to use derivatives and the hedging decisions had to fall into the professional area of the respondent's responsibility. We restricted participation to respondents from firms in the United States or the United Kingdom. These restrictions were included in the announcement of the survey and queried using the first questions in the questionnaire; only participants who answered "yes" to these questions were allowed to continue the survey. The initial reply rate was $87 \% .135$ respondents were disqualified because of our screening and qualification questions, and 161 respondents did not complete the survey. We included an attention check in our actual survey (Kung et al., 2018) to lessen the concern of careless responses. ${ }^{2}$ A total of 333 respondents did not pass the attention check and, thus, were excluded. Eighteen respondents did not provide answers to all items needed for the analysis, leaving 412 complete questionnaires for the analysis. The average time needed to complete the questionnaire was 11 minutes.

Table 1 shows the distribution of respondents across industries, firm size, and firm structures. We proxy the size of the firms with the number of employees and sales revenue. The sample includes an overrepresentation of firms in the financial sector, with almost $54 \%$ of all observations. The sample includes public (38.11\%), private, and governmentowned firms $(6.07 \%)$. The majority of private firms are nonfamily-owned (42.96\%), but the sample also includes almost $13 \%$ of family-owned firms.

The unit of analysis is risk managers' corporate hedging decisions. Table 2 summarizes the personal characteristics

\footnotetext{
2 We presented the following prompt to the participants, "Everyone has hobbies. Nevertheless, we would like you to skip this question to show that you are reading carefully. Do not click any of the buttons corresponding to bike riding, hiking, swimming, playing sports, reading or watching TV." We also provided the following options: bike riding, hiking, swimming, playing sports, reading, and watching TV.
}

Table 1 Characteristics of respondents' firms

\begin{tabular}{|c|c|}
\hline & Percent \\
\hline \multicolumn{2}{|l|}{ Industry } \\
\hline Agriculture, forestry, fishing & 1.70 \\
\hline Mining & 0.73 \\
\hline Manufacturing & 12.86 \\
\hline Transportation \& public utilities & 3.64 \\
\hline Wholesale trade & 2.67 \\
\hline Retail trade & 14.56 \\
\hline Finance, insurance, real estate & 54.37 \\
\hline Services & 5.58 \\
\hline Public administration & 2.43 \\
\hline Unclassified industry & 1.46 \\
\hline \multicolumn{2}{|l|}{ No. employees } \\
\hline $1-50$ & 4.13 \\
\hline $51-250$ & 14.08 \\
\hline $251-500$ & 22.57 \\
\hline $501-1000$ & 24.27 \\
\hline $1001-5000$ & 22.33 \\
\hline $5001-10,000$ & 7.28 \\
\hline $10,001-25,000$ & 2.67 \\
\hline 25,001 or more & 2.67 \\
\hline \multicolumn{2}{|l|}{ Sales revenue } \\
\hline 0-999,999 & 1.70 \\
\hline $1,000,000-4,999,999$ & 10.68 \\
\hline $5,000,000-9,999,999$ & 14.08 \\
\hline $10,000,000-99,999,999$ & 23.54 \\
\hline $100,000,000-999,999,999$ & 23.79 \\
\hline $1,000,000,000-4,999,999,999$ & 13.59 \\
\hline $5,000,000,000-9,999,999,999$ & 7.04 \\
\hline $10,000,000,000$ or above & 5.58 \\
\hline \multicolumn{2}{|l|}{ Firm type } \\
\hline Public firm & 38.11 \\
\hline Private firm & 42.96 \\
\hline Family firm & 12.86 \\
\hline Government firm & 6.07 \\
\hline
\end{tabular}

of the respondents. The majority of the respondents were between 35 and 44 years old, male, and held a graduate degree. Additionally, more than $90 \%$ of respondents had at least 3 years of experience / tenure with the organization.

Common method bias is an important issue when using data collected through surveys. We attempt to reduce common method bias by following best practices to enhance the validity of our survey procedure and by using both procedural and statistical remedies that have been employed by other researchers (Fowler, Jr. 2013; Bergman, et al. 2020). We measure the dependent and independent variables at a maximum distance within the survey (Chang et al., 2010; Podsakoff et al., 2003). We also measure the independent variable of interest with negatively loaded items and hide 
Table 2 Personal characteristics of the respondents

\begin{tabular}{|c|c|}
\hline & Percent \\
\hline \multicolumn{2}{|l|}{ Age } \\
\hline 18 to 34 & 24.27 \\
\hline 35 to 44 & 55.83 \\
\hline 45 to 54 & 16.99 \\
\hline $55+$ & 2.91 \\
\hline \multicolumn{2}{|l|}{ Gender } \\
\hline Female & 28.64 \\
\hline Male & 71.36 \\
\hline \multicolumn{2}{|l|}{ Residence } \\
\hline United States & 52.67 \\
\hline United Kingdom & 47.33 \\
\hline \multicolumn{2}{|l|}{ Education } \\
\hline High school / GED & 5.34 \\
\hline Undergraduate degree & 17.23 \\
\hline Graduate degree & 40.78 \\
\hline MBA & 26.70 \\
\hline Other Non-MBA & 2.43 \\
\hline Ph.D. & 7.52 \\
\hline \multicolumn{2}{|l|}{ Derivatives expertise } \\
\hline$<1$ year & 0.73 \\
\hline $1-2$ years & 9.71 \\
\hline $3-5$ years & 39.32 \\
\hline $6-10$ years & 41.50 \\
\hline$>10$ years & 8.74 \\
\hline \multicolumn{2}{|l|}{ Experience / tenure } \\
\hline$<1$ year & 0.24 \\
\hline $1-2$ years & 5.10 \\
\hline $3-5$ years & 29.37 \\
\hline $6-10$ years & 46.60 \\
\hline$>10$ years & 18.69 \\
\hline \multicolumn{2}{|l|}{ Professional position } \\
\hline Director/Manager corporate risk management & 83.25 \\
\hline Other employee with decision-making power & 16.50 \\
\hline Not a managing position & 0.24 \\
\hline
\end{tabular}

them among a positively loaded scale, which further reduces bias (Mutschmann et al., 2021). We use the Harman (1976) single-factor test to test whether the correlations between the variables are artificially inflated and find that a single factor can explain $21.5 \%$ of the variance, indicating low common method bias.

\section{Variables}

\section{Dependent Variables}

We ask the participants about their corporate hedging practices using various questions that allow us to capture different dimensions of selective hedging. Our questions on selective hedging activities are inspired by prior studies on hedging practices (Bodnar et al., 1998; Phillips, 1995).

Trade for profit We ask the participants to rate their answers to the question, "What best describes the purpose of your derivatives usage?" on an 11-level Likert item ranking from "Reduce cash flow / earnings volatility" to "Trading for profit." Risk managers have, on average, a strong tendency to trade for profits, with a mean of 8.54 and a median of 9 . The standard deviation is 2.08 (see Table 3).

Market view We ask participants about the extent to which their view of the market influences their hedging decisions. We ask, "How often does your market view cause you to... (i) alter the timing of hedges, (ii) alter the size of hedges, and (iii) actively take positions in derivatives?" using 5-level Likert items ranging from "Never" to "Very frequently." We aggregate the answers to a single variable using the average $($ Cronbach's alpha $=0.72)$. Risk managers seem to consider their market view to a large extent when making hedging decisions, as indicated by a mean of 3.96 (standard deviation of 0.69 ) and a median of 4.

Selective hedging We create a variable that aggregates the various dimensions of selective hedging behavior using an 8 -item scale. Four of those eight items come from our variables trade for profit and market view. We complement these items with questions on the extent to which participants use various hedging practices. In total, the scale contains the following questions:

1. How important do you consider trading for profit for your hedging decisions? (Ranges from "Never" to "Very frequently")

2. How often do you use derivatives to reduce costs / increase profits by arbitraging the markets? (Ranges from "Never" to "Very frequently")

3. How often do you use derivatives to reduce costs / increase profits by taking a view? (Ranges from "Never" to "Very frequently")

4. How important do you rate the profit potential when you consider choosing a derivative product? (Ranges from "Not at all important" to "Very important")

5. What best describes the purpose of your derivatives usage? (Ranges from "Reduce cash flow / earnings volatility" to "Trading for profit")

6. How often does your market view cause you to alter the timing of hedges? (Ranges from "Never" to "Very frequently")

7. How often does your market view cause you to alter the size of hedges? (Ranges from "Never" to "Very frequently")

8. How often does your market view cause you to actively take positions in derivatives? (Ranges from "Never" to "Very frequently") 
Fig. 1 Distribution of the dependent variable, "Selective hedging"

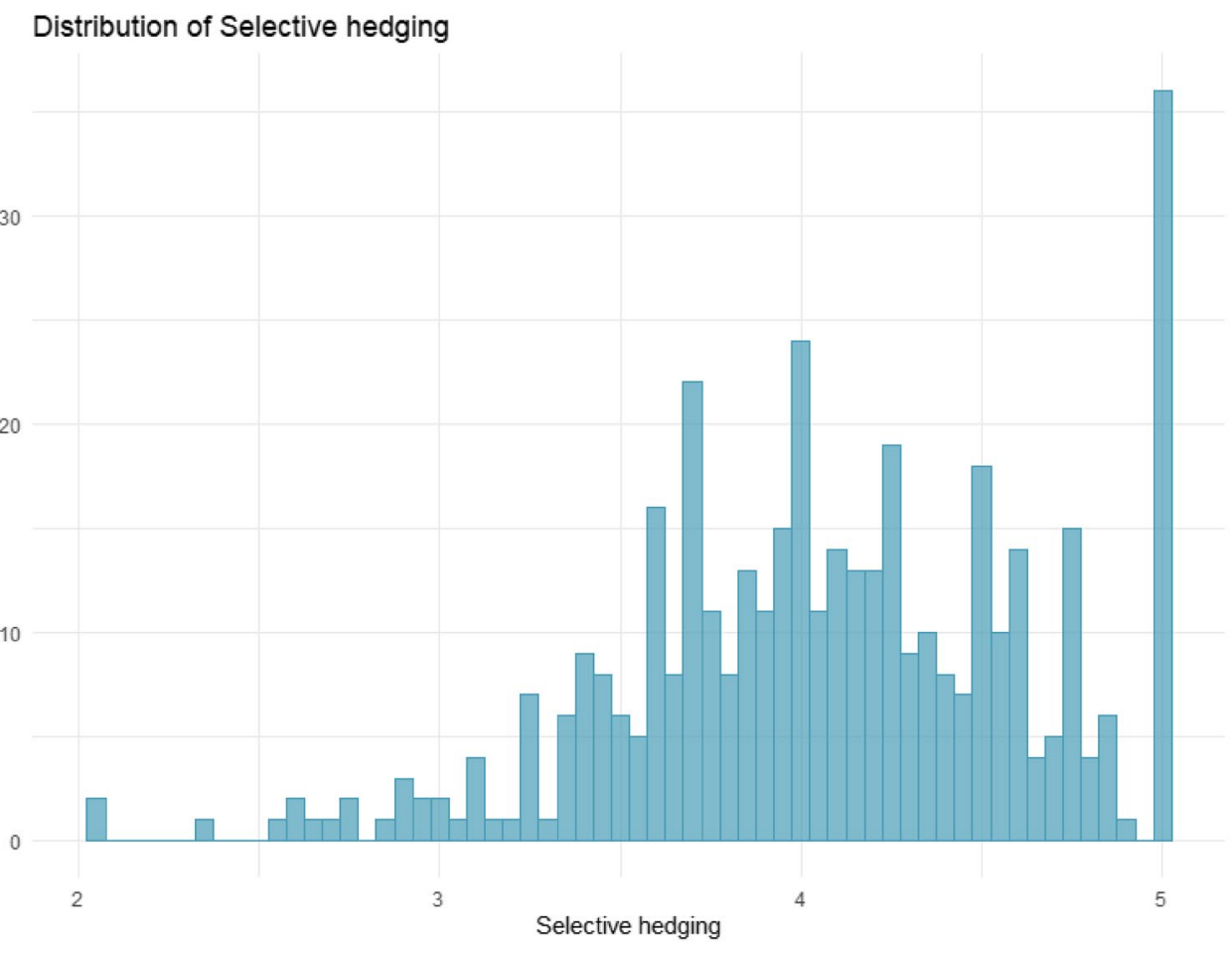

We obfuscate the selective hedging items among a number of other statements that focus on corporate hedging preferences and activities to ensure that participants are not immediately made aware of the focus of the study. We aggregate the variables that capture the various dimensions of selective hedging behavior to a single variable by first scaling all items to a range from 1 to 5 (if necessary) and then taking the average of all items. The internal consistency of the selective hedging measure is very high (Cronbach's alpha = 0.82). Figure 1 shows the distribution of Selective hedging. With a mean and a median of 4.09 (standard deviation of 0.57 ), the variable indicates that risk managers in our sample engage in selective hedging practices. Given the large number of risk managers who show the maximum value of five, we are concerned that several respondents systematically ticked the maximum value, which may distort our results. Consequently, we carefully check whether participants systematically chose one value for all survey questions and find meaningful variation across replies for all respondents.

\section{Independent Variable}

Dark triad We ask the participants about the extent to which they agreed with a set of short statements that include the dirty dozen scale (Jonason \& Webster, 2010). The scale comprises three four-item subscales for Machiavellianism, narcissism, and (subclinical) psychopathy. Specifically, the scale contains the following questions, with 5-levels ranging from "Disagree strongly" to "Agree strongly":
M1 I have used deceit or lied to get my way.

M2 I tend to manipulate others to get my way.

M3 I have used flattery to get my way.

M4 I tend to exploit others toward my own end.

N1 I tend to want others to admire me.

$\mathrm{N} 2$ I tend to want others to pay attention to me.

N3 I tend to expect special favors from others.

N4 I tend to seek prestige or status.

P1 I tend to lack remorse.

P2 I tend to be callous or insensitive.

P3 I tend to not be too concerned with morality or the morality of my actions.

P4 I tend to be cynical.

The dirty dozen scale has been previously used and validated to measure dark triad personality traits (Webster \& Jonason, 2013). To mitigate the potential impact of social desirability bias in our measure of respondents' dark personality traits, we hide the dirty dozen scale within a large number of positively loaded items that assess leadership behavior and other personality traits. We randomize the order of all of the questions to alleviate the possible bias of negatively framed questions. We opt for the dirty dozen because this shorter scale allows us to hide the items properly, and it can be answered in a short time. The Cronbach's alpha of the dark triad scale is 0.92 , indicating very high internal consistency. Figure 2 shows the distribution of the main explanatory variable. We observe a fairly uniform distribution with 
Fig. 2 Distribution of the independent variable, "Dark triad"

\section{Distribution of Dark triad}

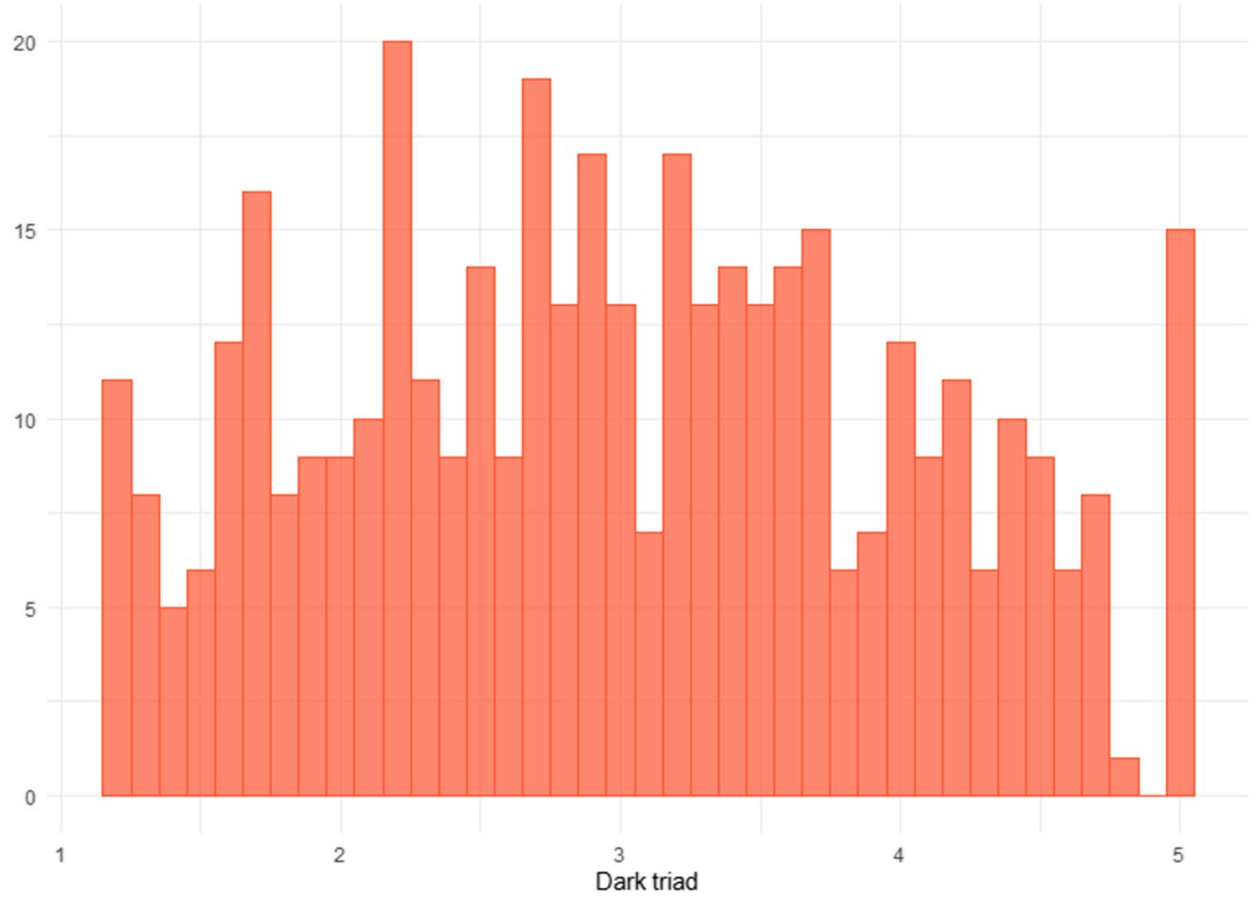

Table 3 Summary statistics

\begin{tabular}{|c|c|c|c|c|c|c|c|c|}
\hline & $\mathrm{N}$ & Mean & $\mathrm{SD}$ & Min & 25 & Median & 75 & Maximum \\
\hline Selective hedging & 412 & 4.0863 & 0.5684 & 2.0250 & 3.7250 & 4.0875 & 4.5250 & 5.0000 \\
\hline Trade for profit & 412 & 8.5388 & 2.0848 & 1.0000 & 8.0000 & 9.0000 & 10.0000 & 11.0000 \\
\hline Market view & 412 & 3.9579 & 0.6889 & 1.0000 & 3.3333 & 4.0000 & 4.3333 & 5.0000 \\
\hline Dark triad & 412 & 3.0051 & 1.0157 & 1.1667 & 2.1667 & 2.9583 & 3.7500 & 5.0000 \\
\hline Machiavellianism & 412 & 2.7203 & 1.2603 & 1.0000 & 1.5000 & 2.7500 & 3.8125 & 5.0000 \\
\hline Narcissism & 412 & 3.4132 & 1.0352 & 1.0000 & 2.7500 & 3.5000 & 4.2500 & 5.0000 \\
\hline Psychopathy & 412 & 2.8817 & 1.1557 & 1.0000 & 2.0000 & 2.7500 & 3.7500 & 5.0000 \\
\hline Risk preference & 412 & 8.8252 & 1.9303 & 1.0000 & 8.0000 & 9.0000 & 11.0000 & 11.0000 \\
\hline Confidence & 412 & 9.0801 & 1.6333 & 2.0000 & 8.0000 & 9.0000 & 11.0000 & 11.0000 \\
\hline Tail outcomes & 412 & 4.1553 & 0.6461 & 1.5000 & 4.0000 & 4.0000 & 4.5000 & 5.0000 \\
\hline Success $=$ profitability & 412 & 0.5121 & 0.5005 & 0.0000 & 0.0000 & 1.0000 & 1.0000 & 1.0000 \\
\hline Performance measurement & 412 & 4.3689 & 0.7891 & 1.0000 & 4.0000 & 5.0000 & 5.0000 & 5.0000 \\
\hline Reporting frequency & 412 & 4.2694 & 1.1282 & 1.0000 & 3.0000 & 4.0000 & 5.0000 & 6.0000 \\
\hline Centralization & 412 & 8.5316 & 2.0305 & 1.0000 & 8.0000 & 9.0000 & 10.0000 & 11.0000 \\
\hline Guidelines & 412 & 3.6141 & 1.1501 & 0.0000 & 3.0000 & 4.0000 & 4.2500 & 5.0000 \\
\hline
\end{tabular}

Variable definitions can be found in Table 9 in the Appendix

several observations, obtaining the largest possible value of five as well. A comparison with other studies on the personality trait shows that the distribution in our sample is similar to the distributions reported in other studies that do not explicitly target risk managers (see e.g.Crysel et al., 2013; Jonason \& Webster, 2010).

\section{Control Variables}

Risk preference We elicit respondents' risk preferences using their responses to the question, "How do you see yourself: are you generally a person who is fully prepared to take risks or do you try to avoid taking risks?" on an 11-level 
Likert item from "not at all willing to take risks" to "very willing to take risks" following the suggestion of Dohmen et al. (2011).

Success = profitability We proxy risk managers' perception that creating (additional) financial gains is an important success criterion (compared with, for example, reduced volatility relative to a benchmark) through their responses to the questions, "How successful in managing company risk would you characterize your derivatives' usage over the last three years?" and "How profitable would you characterize your derivatives' usage over the last three years?" on 11-level Likert items. We then create a dummy variable that takes the value of one for managers who provide the same reply to both questions and zero otherwise. The idea is that, on average, risk managers who perceive financial gains as an important success criterion are more likely to reply identically to both questions than those who do not.

Confidence Motivated by evidence on the impact of confidence on risk managers' selective hedging activities (Adam et al. 2015), we control for participants' level of confidence in their (selective) hedging activities. We measure respondents' confidence in their hedging decisions with the help of a one-item measure based on Weber and Brewer (2003). Specifically, we ask "How confident are you usually in the derivatives positions that you take?" on an 11-level Likert item ranging from "not at all confident" to "very confident."

Derivatives expertise We measure managers' expertise with derivatives using a 5-level item ranging from less than one year to more than 10 years.

Experience / tenure We measure managers' tenure with the company using a 5-level item ranging from less than one year to more than 10 years.

Performance measurement The evaluation of the risk manager's performance might provide these managers with incentives to engage in selective hedging activities to improve their performance evaluation. Hence, we ask participants to indicate the importance of the absolute profit/loss when assessing their performance as a risk manager using a 5-level Likert item ranging from "Not at all important" to "Very important." On average, the absolute profit/loss is highly important for the evaluation of the performance of risk managers in our sample, as indicated by a mean of 4.4 and a median of 5 .

Guidelines We use a scale ranging from "very restrictive policy" to "No, there is no such policy or guidelines at all" to ask the participants about the extent to which they are bound in their corporate hedging decisions by internal guidelines. For our analysis, we invert the scale such that high values indicate a restrictive policy.

Centralization We ask participants to rate the degree of centralization of the hedging activities within their firms ("Please rate your organizations' degree of centralization associated with the usage of derivative contracts to manage risk exposure.") on an 11-level Likert item. With a mean of 8.53 and a standard deviation of 2.03, risk management activities in our sample are fairly centralized.

Reporting frequency We measure the reporting frequency on derivatives usage using participants' replies to the question, "How often do you report to your supervisors / the board on your derivatives activities?" on a 6-level item ranging from never to daily. The items are "Never," "Annually," "Quarterly," "Monthly," "Weekly," and "Daily."

Tail outcomes We ask participants how important they consider eliminating the possibility of extreme losses for their hedging decisions and how often they use derivatives to eliminate lower-tail outcomes on 5-level Likert items. We aggregate the answers to a single variable by taking the average. A mean of 4.15 (standard deviation 0.65 , median 4) indicates that risk managers in our sample consider eliminating lower-tail outcomes to be an important part of their hedging decisions.

Additional control variables We include several additional control variables in our analysis. We collect information about participants' age, gender, education, residence, and their current position. We summarize the characteristics of the respondents in Table 2. We also control for firm size, measured using the number of employees and sales, firm structure (i.e., public firm, private firm, family firm, and government firm), and industry with full sets of dummy variables. We summarize all variable definitions in Table 9 in the Appendix.

\section{Model Estimation}

We estimate the following main model using a standard ordinary least squares (OLS) model with robust standard errors (MacKinnon and White 1985):

$$
\begin{aligned}
\text { Selective hedging }_{i}= & \alpha+\beta{\text { dark } \text { triad }_{i}}^{J} \\
& +\sum_{j=1}^{J} \gamma_{j} \text { controls }_{i j}+\epsilon_{i}
\end{aligned}
$$

\section{Results}

\section{Pearson's Correlation Matrix}

Table 4 reports the Pearson correlations. We observe a strong positive correlation between the selective hedging variable and the different dimensions of selective hedging. We also observe a significantly positive correlation between the dark triad and selective hedging and the different dimensions of selective hedging. Thus, bivariate correlations provide initial support for our first hypothesis. 


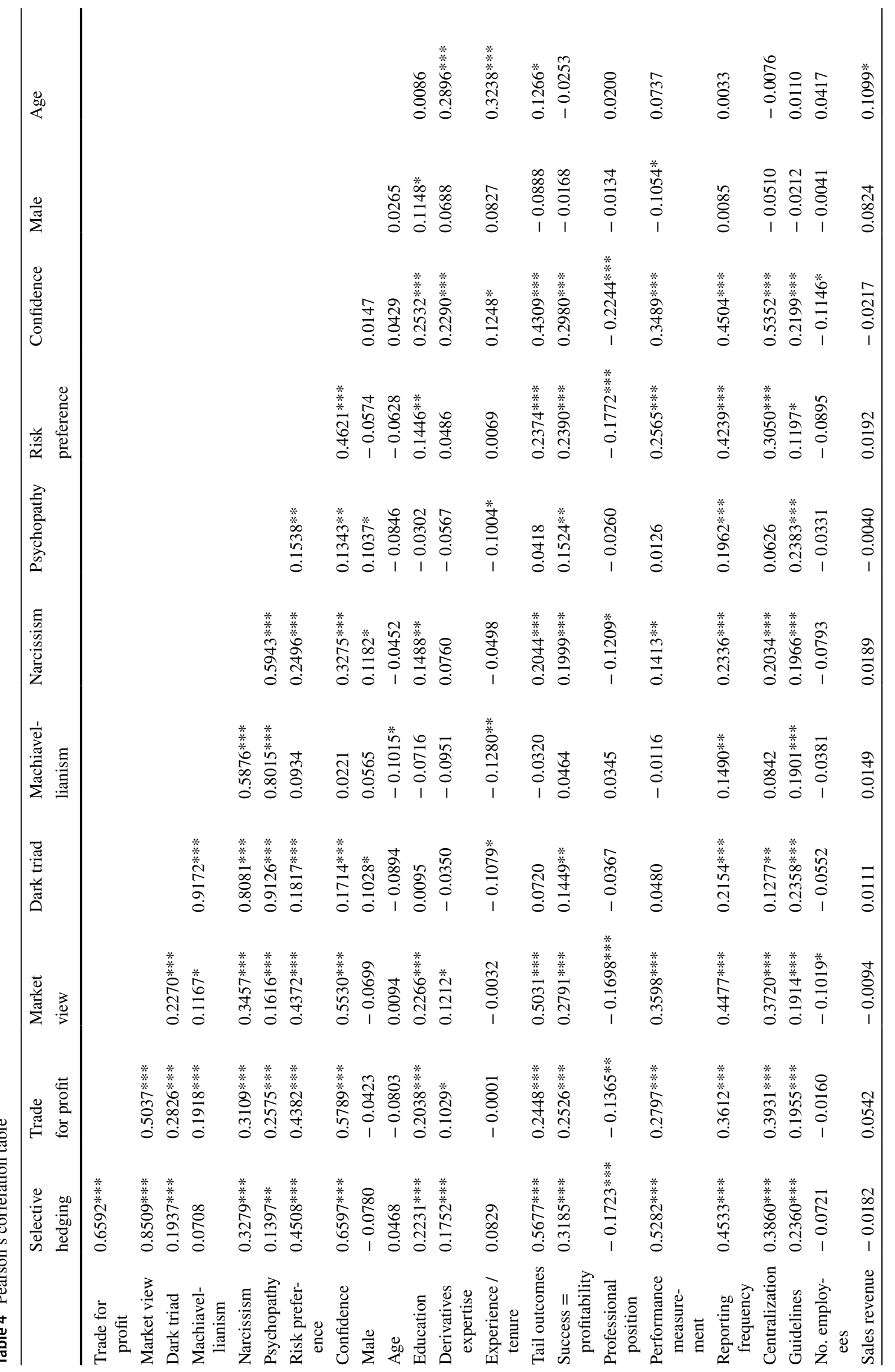




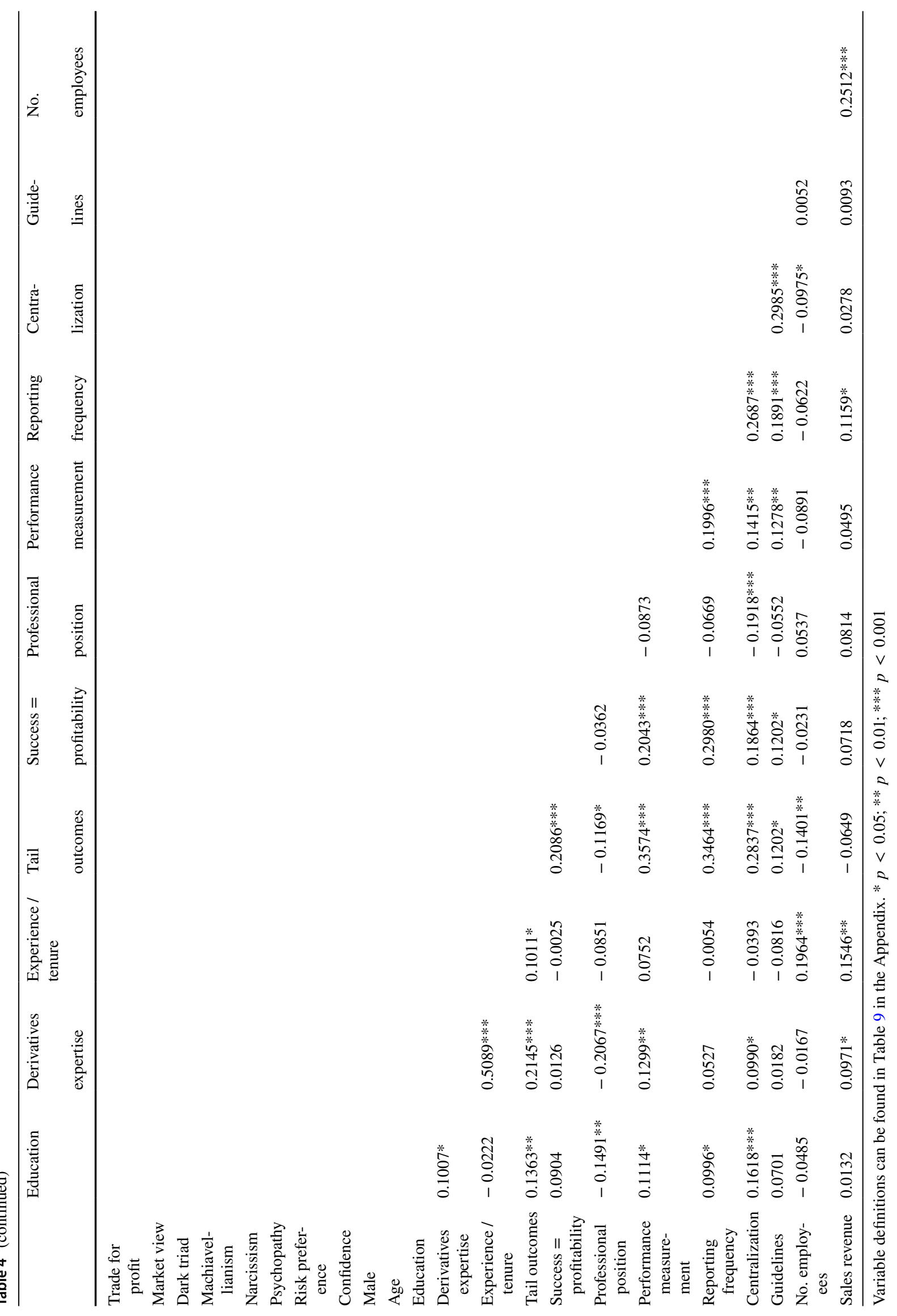


High correlations between Machiavellianism, narcissism, and psychopathy support the notion of a significant overlap of these personality traits.

We also observe strong positive correlations between selective hedging activities and risk managers' risk preferences, confidence levels, education, and derivatives expertise. Risk managers who are particularly concerned with lower tail outcomes are also more engaged in selective hedging activities.

While we also observe several positive correlations between our control variables, multicollinearity is not an issue in our regressions, as none of the correlations are above .7. Generalized variance inflation factors below 3 also indicate that multicollinearity is not an issue.

\section{Hypothesis Testing}

Table 5 presents our main regression results. Column (1) indicates a positive regression coefficient of 0.0384 on Dark triad, with a $t$-statistic of 2.16. The coefficient suggests that a one-unit increase in Dark triad explains approximately $6.6 \%$ $(=0.04 / 0.6)$ of the standard deviation of selective hedging. To put this into perspective, the coefficient of Dark triad is slightly larger than the coefficient of risk preferences, indicating a somewhat larger effect size when comparing the two variables. However, when interpreting the effect size, keep in mind that estimating precise effect sizes is a task that is better suited for large-scale archival studies (Libby et al., 2002). We focus on the trade-off between reducing the volatility of earnings and cash flows versus trading for profit in column (2), with risk managers with more pronounced dark personality traits having a clear preference for trading for profit (coefficient of 0.3194 ; $t$-statistic of 3.65). Economically, a one-unit increase in Dark triad explains approximately $15 \%$ of the standard deviation of Trade for profit. We find statistically significant and positive coefficients in column (3) as well. These results are consistent with Hypothesis H1: Managers who score high on the dark triad personality scale engage more heavily in selective hedging activities.

Control variables, such as managers' risk preference $(0.03, t$-statistic of 2.21) and confidence $(0.11, t$-statistic of 6.36), are in line with the prior literature (Pennings \& Garcia, 2004; Adam et al., 2015). We also find that managers concerned with lower-tail outcomes engage more in selective hedging $(0.22, t$-statistic of 5.67).

To alleviate the concern that one particular trait of the dark triad, for example, narcissism, might explain our results, we provide results using the subscales for the individual traits as main explanatory variables in Table 10 in the Appendix. We observe positive and significant coefficients of similar magnitude for all traits, with the coefficient of Psychopathy on Selective hedging being the only exception. This observation provides additional support for the use of the composite dark triad measure. We also address the concern that participants from the financial sector are the main driver of our findings. We summarize the results excluding respondents from the financial sector in Table 11. Our conclusions are not (exclusively) driven by respondents from the financial sector. The coefficients on selective hedging $(0.0613, t$-statistic of 2.03), trade for profit $(0.3751$, $t$-statistic of 2.81), and market view (0.0802, $t$-statistic of 1.76) are slightly larger than in the main analysis but also have somewhat larger standard errors.

We next study the moderating function of demographic factors. We add a set of interaction variables to Eq. (1). We first interact Dark triad with our dummy variable for male managers. To simplify the interpretability of the results, we separately report the coefficients for Dark triad for female managers (Dark triad female) and for male managers (Dark triad male). This approach simplifies the readability of the effect sizes and captures the entire domains of both the dark triad and the relevant dummy, while being otherwise completely equivalent to a standard interaction approach. ${ }^{3}$ In column (1) of Table 6 we find a positive coefficient on Dark triad male $(0.0487, t$-statistic of 2.23$)$, whereas the coefficient for female managers $(0.0166, t$-statistic of 0.62$)$ is not significantly different from zero. The relationship between the Dark triad and Selective hedging is less pronounced for female risk managers, in line with Hypothesis $\mathrm{H} 2$.

In column (2), we turn to the moderating function of age. We classify managers who are 44 years of age or younger as "young" and managers who are 45 years or older as "old". The results suggest that the relationship between Dark triad and Selective hedging is particularly pronounced for older risk managers. We observe a positive coefficient on Dark triad old $(0.0745, t$-statistic of 2.16) and a coefficient of 0.0271 ( $t$-statistic of 1.36) on Dark triad young. Thus, the overall support for Hypothesis $\mathrm{H} 2$ is mixed.

In column (3), we study the moderating function of experience. Using a median split our findings indicate that the relationship between Dark triad and Selective hedging is particularly pronounced for risk managers who are less experienced. We find a positive coefficient on Dark triad short tenure $(0.09, t$-statistic of 3.59) but not on Dark triad long tenure $(0.0108, t$-statistic of 0.50$)$ - in line with Hypothesis H3.

Turning to Hypothesis H4, we observe a positive coefficient on Dark triad high education (column 4, 0.04, $t$-statistic

\footnotetext{
3 A "traditional" interaction term in a regression is the product of two terms. However, using such an interacted regressor has one disadvantage when it comes to readability: it requires mental arithmetic, not only to quantify the effect size but also to determine the standard errors of the effect sizes of both groups that are part of the interaction. Making use of a simple modification and including two "interaction" terms simplifies this issue and allows the reader to immediately read both coefficients and standard errors directly from the table.
} 
Table 5 Managerial dark triad personality and selective hedging

\begin{tabular}{|c|c|c|c|}
\hline & \multicolumn{3}{|l|}{ Dependent variable } \\
\hline & $\begin{array}{l}\text { Selective hedging } \\
\text { (1) }\end{array}$ & $\begin{array}{l}\text { Trade for profit } \\
\text { (2) }\end{array}$ & $\begin{array}{l}\text { Market view } \\
\text { (3) }\end{array}$ \\
\hline Constant & $\begin{array}{l}0.4338^{* *} \\
(1.9969)\end{array}$ & $\begin{array}{l}-0.0485 \\
(-0.0522)\end{array}$ & $\begin{array}{l}0.4344 \\
(1.2592)\end{array}$ \\
\hline Dark triad & $\begin{array}{l}0.0384^{* *} \\
(2.1621)\end{array}$ & $\begin{array}{l}0.3194^{* * *} \\
(3.6537)\end{array}$ & $\begin{array}{l}0.0779^{* * *} \\
(3.1826)\end{array}$ \\
\hline Risk preference & $\begin{array}{l}0.0284^{* *} \\
(2.2051)\end{array}$ & $\begin{array}{l}0.1529^{*} \\
(1.8278)\end{array}$ & $\begin{array}{l}0.0405^{* *} \\
(2.1808)\end{array}$ \\
\hline Confidence & $\begin{array}{l}0.1056^{* * *} \\
(6.3609)\end{array}$ & $\begin{array}{l}0.5098^{* * *} \\
(6.3310)\end{array}$ & $\begin{array}{l}0.0744^{* * *} \\
(3.0401)\end{array}$ \\
\hline Male & $\begin{array}{l}-0.0531 \\
(-1.3792)\end{array}$ & $\begin{array}{l}-0.2186 \\
(-1.2583)\end{array}$ & $\begin{array}{l}-0.0996^{*} \\
(-1.8711)\end{array}$ \\
\hline Age (18-34) & $\begin{array}{l}0.0203 \\
(0.4389)\end{array}$ & $\begin{array}{l}0.3267^{*} \\
(1.8463)\end{array}$ & $\begin{array}{l}-0.0543 \\
(-0.8702)\end{array}$ \\
\hline Age (45-54) & $\begin{array}{l}0.0361 \\
(0.7119)\end{array}$ & $\begin{array}{l}-0.1716 \\
(-0.5563)\end{array}$ & $\begin{array}{l}0.0291 \\
(0.4349)\end{array}$ \\
\hline Age $(55+)$ & $\begin{array}{l}0.0176 \\
(0.1712)\end{array}$ & $\begin{array}{l}-0.2810 \\
(-0.4359)\end{array}$ & $\begin{array}{l}-0.1496 \\
(-0.9015)\end{array}$ \\
\hline Education & $\begin{array}{l}0.0209 \\
(1.3501)\end{array}$ & $\begin{array}{l}0.1158 \\
(1.4981)\end{array}$ & $\begin{array}{l}0.0415^{*} \\
(1.8484)\end{array}$ \\
\hline Derivatives expertise & $\begin{array}{l}0.0054 \\
(0.1689)\end{array}$ & $\begin{array}{l}0.1248 \\
(0.9276)\end{array}$ & $\begin{array}{l}0.0140 \\
(0.2918)\end{array}$ \\
\hline Experience / tenure & $\begin{array}{l}0.0025 \\
(0.0756)\end{array}$ & $\begin{array}{l}-0.0613 \\
(-0.4406)\end{array}$ & $\begin{array}{l}-0.0480 \\
(-1.0044)\end{array}$ \\
\hline Tail outcomes & $\begin{array}{l}0.2193^{* * *} \\
(5.6668)\end{array}$ & $\begin{array}{l}-0.1560 \\
(-1.0692)\end{array}$ & $\begin{array}{l}0.2703^{* * *} \\
(5.2686)\end{array}$ \\
\hline Success $=$ profitability & $\begin{array}{l}0.0666 \\
(1.6204)\end{array}$ & $\begin{array}{l}0.1518 \\
(0.9168)\end{array}$ & $\begin{array}{l}0.0826 \\
(1.4559)\end{array}$ \\
\hline Professional position & $\begin{array}{l}-0.0139 \\
(-0.2523)\end{array}$ & $\begin{array}{l}0.0941 \\
(0.4532)\end{array}$ & $\begin{array}{l}-0.0520 \\
(-0.7132)\end{array}$ \\
\hline Performance measurement & $\begin{array}{l}0.1855^{* * *} \\
(5.2300)\end{array}$ & $\begin{array}{l}0.2384^{*} \\
(1.8189)\end{array}$ & $\begin{array}{l}0.0882^{* *} \\
(2.0477)\end{array}$ \\
\hline Reporting frequency & $\begin{array}{l}0.0406^{* *} \\
(2.0173)\end{array}$ & $\begin{array}{l}0.0481 \\
(0.5389)\end{array}$ & $\begin{array}{l}0.0803^{* * *} \\
(2.8290)\end{array}$ \\
\hline Centralization & $\begin{array}{l}0.0032 \\
(0.3228)\end{array}$ & $\begin{array}{l}0.1102^{*} \\
(1.9652)\end{array}$ & $\begin{array}{l}0.0191 \\
(1.3209)\end{array}$ \\
\hline Guidelines & $\begin{array}{l}0.0227 \\
(1.2634)\end{array}$ & $\begin{array}{l}-0.0241 \\
(-0.3198)\end{array}$ & $\begin{array}{l}-0.0038 \\
(-0.1287)\end{array}$ \\
\hline No. employees & $\begin{array}{l}0.0059 \\
(1.6459)\end{array}$ & $\begin{array}{l}0.0290 \\
(1.4343)\end{array}$ & $\begin{array}{l}0.0015 \\
(0.3141)\end{array}$ \\
\hline Sales revenue & $\begin{array}{l}-0.0006 \\
(-1.0023)\end{array}$ & $\begin{array}{l}0.0038 \\
(1.2379)\end{array}$ & $\begin{array}{l}0.0002 \\
(0.1715)\end{array}$ \\
\hline Private firm & $\begin{array}{l}-0.0258 \\
(-0.6686)\end{array}$ & $\begin{array}{l}-0.4164^{* *} \\
(-2.3761)\end{array}$ & $\begin{array}{l}-0.1095^{* *} \\
(-2.0241)\end{array}$ \\
\hline Family firm & $\begin{array}{l}-0.0811 \\
(-1.2307)\end{array}$ & $\begin{array}{l}-0.2055 \\
(-0.9022)\end{array}$ & $\begin{array}{l}-0.2296^{* *} \\
(-2.3679)\end{array}$ \\
\hline Government firm & $\begin{array}{l}-0.0138 \\
(-0.2487)\end{array}$ & $\begin{array}{l}-0.0915 \\
(-0.2994)\end{array}$ & $\begin{array}{l}-0.1077 \\
(-1.3256)\end{array}$ \\
\hline Industry effects & Yes & Yes & Yes \\
\hline Country effects & Yes & Yes & Yes \\
\hline
\end{tabular}


Table 5 (continued)

\begin{tabular}{llll}
\hline & \multicolumn{2}{l}{ Dependent variable } & \\
\cline { 2 - 4 } & Selective hedging & Trade for profit & Market view \\
& $(1)$ & $(2)$ & $(3)$ \\
\hline Observations & 412 & 412 & 412 \\
Adjusted R & 0.6244 & 0.4202 & 0.4906 \\
Residual SE & 0.3484 & 1.5875 & 0.4917 \\
F Statistic & $22.3552^{* * *}$ & $10.3067^{* * *}$ & $13.3681^{* * *}$ \\
\hline
\end{tabular}

Regression coefficients are presented with $t$-values in parentheses and robust standard errors (MacKinnon and White 1985). ${ }^{*} p<0.1 ;{ }^{* *} p<0.05 ;{ }^{* * *} p<0.01$. Variable definitions of control variables can be found in Table 9 in the Appendix

of 2.16) and a coefficient of zero on Dark triad low education (0.0106, $t$-statistic of 0.27$)$. As an alternative proxy for education, we take risk managers' experience trading with derivatives (column 5). The rationale behind this proxy is that managers with significant experience in trading derivatives are educated in the field. Overall, the findings are in line with Hypothesis H4.

With respect to Hypotheses H5 and H6 and the moderating function of the reporting frequency and the perception of successful risk management, respectively, we first interact reporting frequency (median split) with the Dark triad variable in Table 7, and find some support for Hypothesis H5.

Column (2) of Table 7 shows that the relationship between dark triad personality traits and selective hedging activities is particularly pronounced for risk managers who perceive generating additional profits through hedging activities as a success, providing support for Hypothesis H6. The coefficient on Dark triad success $=$ profitability is 0.05 and statistically significant ( $t$-statistic of 2.35 ), whereas the coefficient on Dark triad success $\neq$ profitability $(0.0214)$ is statistically not different from zero.

Finally, we turn to Hypothesis H7. We use various proxies for managerial discretion. First, we investigate the impact of managers' professional positions on our findings. We distinguish between managers who are directors or managers of corporate risk management and those who are not. Obviously, directors enjoy greater managerial discretion. Column (1) of Table 8 summarizes the results. We find a positive coefficient for risk managers in charge (coefficient of 0.03 , $t$-statistic of 1.71), also suggesting that our findings are not driven primarily by risk managers who are not in charge.

As a second proxy, motivated by the finding that the heterogeneity of hedging behavior can, to some degree, be explained by the firm's ownership structure (Pennings \& Garcia, 2004), we investigate the moderating influence of firm structure. Managers of family firms enjoy more discretion than those of non-family firms. The characteristics of firm owners tend to significantly affect their business strategies (Falkner \& Hiebl, 2015). Family firms do not routinely select employees using common techniques, such as assessment centers, but often put family members in important decision-making positions after they form skills and personalities over the years to be successful future leaders within the family business. In fact, family members who follow in the leadership of the firm might show dark personality traits as a result of their upbringing (Barach \& Ganitsky, 1995). We separately study family-owned firms and non-familyowned firms [column (2) of Table 8]. The coefficient on Dark triad family is 0.09 ( $t$-statistic of 1.86) and larger than the coefficient on Dark triad other (0.03, $t$-statistic of 1.62), suggesting that the relationship between dark personality traits and selective hedging is more pronounced in family firms.

Larger firms and those with a more centralized risk management approach are more likely to have established routines and structures with respect to corporate hedging decisions, leaving less scope for managerial discretion (see also Li \& Tang, 2010). In addition, risk managers with dark personality traits aim to receive attention and admiration for their selective hedging activities. These managers have stronger incentives to engage in such activities when the firm is smaller; then, their impact is relatively higher, ensuring more external admiration for their actions. A similar argument holds when firms have a less centralized risk management approach, making the potential for receiving admiration more pronounced. Our results in columns (3) and (4) of Table 8 indicate that the relationship between Dark triad and Selective hedging is more prevalent in small firms. In column (5) of Table 8, we turn to the degree of centralization of the risk management function and observe a larger effect size in less centralized risk management functions. Overall, these findings provide support for Hypothesis H7. Note that our findings on the moderating role of the manager's age and education are also in line with this hypothesis, considering that older managers - or those with a higher educationlikely enjoy more managerial discretion because of their seniority and education. 
Table 6 Managerial demographics, dark triad personality, and selective hedging

\begin{tabular}{|c|c|c|c|c|c|}
\hline & \multicolumn{5}{|c|}{ Dependent variable } \\
\hline & \multicolumn{5}{|c|}{ Selective hedging } \\
\hline & (1) & (2) & (3) & (4) & (5) \\
\hline Dark triad female & $\begin{array}{l}0.0166 \\
(0.6154)\end{array}$ & & & & \\
\hline Dark triad male & $\begin{array}{l}0.0487^{* *} \\
(2.2284)\end{array}$ & & & & \\
\hline Dark triad young & & $\begin{array}{l}0.0271 \\
(1.3615)\end{array}$ & & & \\
\hline Dark triad old & & $\begin{array}{l}0.0745^{* *} \\
(2.1608)\end{array}$ & & & \\
\hline Young (D) & & $\begin{array}{l}0.1082 \\
(0.7778)\end{array}$ & & & \\
\hline Dark triad short tenure & & & $\begin{array}{l}0.0931^{* * *} \\
(3.5911)\end{array}$ & & \\
\hline Dark triad long tenure & & & $\begin{array}{l}0.0108 \\
(0.4980)\end{array}$ & & \\
\hline Experience / tenure (D) & & & $\begin{array}{l}0.2881^{* *} \\
(2.5159)\end{array}$ & & \\
\hline Dark triad low education & & & & $\begin{array}{l}0.0106 \\
(0.2703)\end{array}$ & \\
\hline Dark triad high education & & & & $\begin{array}{l}0.0427^{* *} \\
(2.1630)\end{array}$ & \\
\hline Education (D) & & & & $\begin{array}{l}-0.0412 \\
(-0.3040)\end{array}$ & \\
\hline Dark triad low derivatives expertise & & & & & $\begin{array}{l}0.0776 \\
(1.4315)\end{array}$ \\
\hline Dark triad high derivatives expertise & & & & & $\begin{array}{l}0.0343^{*} \\
(1.8297)\end{array}$ \\
\hline Derivatives expertise (D) & & & & & $\begin{array}{l}0.1820 \\
(1.0237)\end{array}$ \\
\hline Male & $\begin{array}{l}-0.1470 \\
(-1.3168)\end{array}$ & $\begin{array}{l}-0.0545 \\
(-1.4168)\end{array}$ & $\begin{array}{l}-0.0601 \\
(-1.5626)\end{array}$ & $\begin{array}{l}-0.0495 \\
(-1.2507)\end{array}$ & $\begin{array}{l}-0.0527 \\
(-1.3648)\end{array}$ \\
\hline Controls & Yes & Yes & Yes & Yes & Yes \\
\hline Industry effects & Yes & Yes & Yes & Yes & Yes \\
\hline Country effects & Yes & Yes & Yes & Yes & Yes \\
\hline Observations & 412 & 412 & 412 & 412 & 412 \\
\hline Adjusted $\mathrm{R}^{2}$ & 0.6242 & 0.6265 & 0.6290 & 0.6235 & 0.6245 \\
\hline Residual SE & 0.3485 & 0.3474 & 0.3462 & 0.3488 & 0.3483 \\
\hline F Statistic & $21.6845^{* * *}$ & $23.2403^{* * *}$ & $22.1147^{* * *}$ & $21.6284^{* * *}$ & $21.7155^{* * *}$ \\
\hline
\end{tabular}

Regression coefficients are presented with $t$-values in parentheses and robust standard errors (MacKinnon and White 1985). ${ }^{*} p<0.1 ;{ }^{* *} p<0.05 ;{ }^{* * *} p<0.01$. Variable definitions: Young (D) is a dummy variable that takes the value of one for risk managers who are 44 years of age or younger and zero otherwise; Experience / tenure (D) is a dummy variable that takes the value of one for risk managers with higher than the median experience and zero otherwise; Education (D) is a dummy variable for risk managers who hold a graduate degree or higher and zero otherwise; Derivatives expertise (D) is a dummy variable that takes the value of one for risk managers with higher than the median derivatives expertise and zero otherwise; Dark triad female takes the value of Dark triad for female respondents and zero otherwise; Dark triad male takes the value of Dark triad for male respondents and zero otherwise; Dark triad young takes the value of Dark triad for Young (D) $=1$ and zero otherwise; Dark triad old takes the value of Dark triad for Young (D) $=0$ and zero otherwise; Dark triad short tenure takes the value of Dark triad for Experience / tenure (D) $=0$ and zero otherwise; Dark triad long tenure takes the value of Dark triad for Experience / tenure (D) $=1$ and zero otherwise; Dark triad low education takes the value of Dark triad for Education (D) $=0$ and zero otherwise; Dark triad high education takes the value of Dark triad for Education (D) $=1$ and zero otherwise; Dark triad low derivatives expertise takes the value of Dark triad for Derivatives expertise (D) $=0$ and zero otherwise; Dark triad high derivatives expertise takes the value of Dark triad for Derivatives 
Table 6 (continued)

expertise (D) = 1 and zero otherwise. Variable definitions of control variables can be found in Table 9 in the Appendix

Table 7 Reporting frequency, perception of success, dark triad personality, and selective hedging

\begin{tabular}{|c|c|c|}
\hline & \multicolumn{2}{|c|}{ Dependent variable } \\
\hline & \multicolumn{2}{|c|}{ Selective hedging } \\
\hline & (1) & (2) \\
\hline Dark triad low reporting & $\begin{array}{l}0.0342 \\
(1.2411)\end{array}$ & \\
\hline Dark triad high reporting & $\begin{array}{l}0.0471^{*} \\
(1.9313)\end{array}$ & \\
\hline Reporting frequency (D) & $\begin{array}{l}-0.0096 \\
(-0.0750)\end{array}$ & \\
\hline Dark triad success $=$ profitability & & $\begin{array}{l}0.0504^{* *} \\
(2.3510)\end{array}$ \\
\hline Dark triad success $\neq$ profitability & & $\begin{array}{l}0.0214 \\
(0.7274)\end{array}$ \\
\hline Success $=$ profitability & & $\begin{array}{l}-0.0185 \\
(-0.1598)\end{array}$ \\
\hline Controls & Yes & Yes \\
\hline Industry effects & Yes & Yes \\
\hline Country effects & Yes & Yes \\
\hline Observations & 412 & 412 \\
\hline Adjusted $\mathrm{R}^{2}$ & 0.6197 & 0.6241 \\
\hline Residual SE & 0.3505 & 0.3485 \\
\hline F Statistic & $21.2959^{* * *}$ & $21.6750^{* * *}$ \\
\hline
\end{tabular}

Regression coefficients are presented with $t$-values in parentheses and robust standard errors (MacKinnon and White 1985). ${ }^{*} p<0.1 ;{ }^{* *}$ $p<0.05 ;{ }^{* * *} p<0.01$. Reporting frequency (D) is a dummy variable that takes the value of one for reporting frequencies above the median and zero otherwise; Dark triad low reporting takes the value of Dark triad for Reporting frequency (D) $=0$ and zero otherwise; Dark triad high reporting takes the value of Dark triad for Reporting frequency (D) $=1$ and zero otherwise; Dark triad success $=$ profitability takes the value of Dark triad for Success $=$ profitability $=1$ and zero otherwise; Dark triad success $\neq$ profitability takes the value of Dark triad for success $=$ profitability $=0$ and zero otherwise. Variable definitions of control variables can be found in Table 9 in the Appendix

\section{Implications and Conclusion}

We use a survey setting to study the relation between managerial personality traits and selective hedging activities. We ask managers to rate the importance of particular criteria when selecting their hedging activities. Our results indicate that dark personality traits are positively associated with selective hedging when controlling for various manager and firm characteristics. We also find that the results are more pronounced for male managers, which is consistent with the general notion that women are more risk averse than men (Halek \& Eisenhauer, 2001). We find a stronger effect for older risk managers, which might seem counterintuitive given the well-established idea that individuals' risk aversion increases with age; however, this finding might be particularly interesting because it hints at the possibility that the dark triad effect overwrites the risk aversion effect as an individual ages. The result is also consistent with the notion of Croci et al. (2017), who argue that younger managers prefer to hedge more because they suffer the consequences of an impaired reputation that comes from potential financial distress caused by selective hedging activities over a longer career horizon.

In addition to age and gender, we document that managers' experience and education play an important role in the relationship between their dark triad personality traits and selective hedging activities. We show that less experienced managers are more prone to selective hedging, given pronounced dark triad personality traits-in line with the notion that experience mitigates behavioral biases (Feng \& Seasholes, 2005). Note that age is often used as a proxy for experience but does not necessarily determine experience for highly specialized tasks, such as financial risk management. In support of this notion, we observe a correlation between age and experience of 0.33 in our sample, indicating that these two variables have a common dimension but indeed measure different constructs. Our results on education indicate that risk managers with a higher level of education are more prone to engage in selective hedging when scoring high on the dark triad personality scale, which is also in line with the notion of Beber and Fabbri (2012) that high levels of education are associated with a greater tendency to engage in selective hedging. Our results indicate that the relation between education and selection hedging might be particularly driven by highly educated risk managers with pronounced dark personality traits.

A finding with important practical implications is that risk managers who perceive the isolated profit of hedging decisions to be a measure of success drive the relationship between dark personality traits and selective hedging activities. In addition, we find that the relationship between dark managerial personality traits and selective hedging increases with the manager's discretion; we proxy for managerial discretion with firm structure and firm size. Considering previous evidence that selective hedging is more prevalent in small firms (Adam et al., 2017), which contradicts the notion of Stulz (1996), and when multiple departments are responsible for financial risk management (Aabo et al. 2012), our results indicate that these relationships might be particularly driven by risk managers with pronounced dark personality traits who are responsible for financial risk management in smaller and less centralized firms. Thereby, we add a potential explanation to the literature as to why selective hedging is particularly prevalent in small firms. Although Adam et al. (2017) and Graham and Harvey (2001) suggest that managers of smaller firms might be less sophisticated, 
Table 8 Firm structure, dark triad personality, and selective hedging

\begin{tabular}{|c|c|c|c|c|c|}
\hline & \multicolumn{5}{|c|}{ Dependent variable } \\
\hline & \multicolumn{5}{|c|}{ Selective hedging } \\
\hline & (1) & (2) & (3) & (4) & (5) \\
\hline Dark triad not managing & $\begin{array}{l}0.0869 \\
(1.4610)\end{array}$ & & & & \\
\hline Dark triad managing & $\begin{array}{l}0.0314^{*} \\
(1.7147)\end{array}$ & & & & \\
\hline Professional position (D) & $\begin{array}{l}0.1839 \\
(0.9392)\end{array}$ & & & & \\
\hline Dark triad family & & $\begin{array}{l}0.0936^{*} \\
(1.8560)\end{array}$ & & & \\
\hline Dark triad other & & $\begin{array}{l}0.0302 \\
(1.6241)\end{array}$ & & & \\
\hline Family firm (D) & & $\begin{array}{l}-0.2690 \\
(-1.3334)\end{array}$ & & & \\
\hline Dark triad low sales & & & $\begin{array}{l}0.0681^{* * *} \\
(2.8617)\end{array}$ & & \\
\hline Dark triad high sales & & & $\begin{array}{l}0.0054 \\
(0.2106)\end{array}$ & & \\
\hline Sales revenue (D) & & & $\begin{array}{l}0.1842 \\
(1.6209)\end{array}$ & & \\
\hline Dark triad few employees & & & & $\begin{array}{l}0.0664^{* * *} \\
(2.6037)\end{array}$ & \\
\hline Dark triad many employees & & & & $\begin{array}{l}0.0115 \\
(0.4851)\end{array}$ & \\
\hline No. employees (D) & & & & $\begin{array}{l}0.1752 \\
(1.5763)\end{array}$ & \\
\hline Dark triad less centralized & & & & & $\begin{array}{l}0.0431^{* *} \\
(1.9910)\end{array}$ \\
\hline Dark triad highly centralized & & & & & $\begin{array}{l}0.0299 \\
(0.9217)\end{array}$ \\
\hline Centralization (D) & & & & & $\begin{array}{l}0.1181 \\
(0.8969)\end{array}$ \\
\hline Controls & Yes & Yes & Yes & Yes & Yes \\
\hline Industry effects & Yes & Yes & Yes & Yes & Yes \\
\hline Country effects & Yes & Yes & Yes & Yes & Yes \\
\hline Observations & 412 & 412 & 412 & 412 & 412 \\
\hline Adjusted $\mathrm{R}^{2}$ & 0.6246 & 0.6265 & 0.6259 & 0.6242 & 0.6254 \\
\hline Residual SE & 0.3483 & 0.3474 & 0.3477 & 0.3485 & 0.3479 \\
\hline F Statistic & $21.7207^{* * *}$ & $23.2389^{* * *}$ & $21.8343^{* * *}$ & $21.6858^{* * *}$ & $21.7932^{* * *}$ \\
\hline
\end{tabular}

Regression coefficients are presented with $t$-values in parentheses and robust standard errors (MacKinnon and White 1985). ${ }^{*} p<0.1{ }^{* *} p<0.05 ;{ }^{* * *} p<0.01$. Variable definitions: Professional position (D) is a dummy variable that takes the value of one for risk managers who hold a position as director or manager corporate risk management and zero otherwise; Family firm (D) is a dummy variable that takes the value of one for family firms and zero otherwise; Sales revenue (D) is a dummy variable that takes the value of one for firms with above median sales revenue and zero otherwise; No. employees (D) is a dummy variable that takes the value of one for companies with higher than the median number of employees and zero otherwise; Centralization (D) is a dummy variable that takes the value of one for highly centralized firms and zero otherwise; Dark triad not managing takes the value of Dark triad for Professional position (D) $=0$ and zero otherwise; Dark triad managing takes the value of Dark triad for Professional position (D) $=1$ and zero otherwise; Dark triad family takes the value of Dark triad for Firm type (D) $=1$ and zero otherwise; Dark triad other takes the value of Dark triad for Firm type (D) $=0$ and zero otherwise; Dark triad low sales takes the value of Dark triad for Sales revenue (D) $=0$ and zero otherwise; Dark triad high sales takes the value of Dark triad for Sales revenue $(D)=1$ and zero otherwise; Dark triad few employees takes the value of Dark triad for No. employees $(D)=0$ and zero otherwise; Dark triad many employees takes the value of Dark triad for No. employees (D) $=1$ and zero otherwise. Dark triad less centralized takes the 
Table 8 (continued)

value of Dark triad for centralization (D) $=0$ and zero otherwise; Dark triad highly centralized takes the value of Dark triad for centralization $(D)=1$ and zero otherwise. Variable definitions of control variables can be found in Table 9 in the Appendix

our results show that risk managers with dark personality traits might engage more often in selective hedging-particularly in small firms and potentially as a result of increased managerial discretion in these smaller firms.

Our paper speaks to the ethical dimension of selective hedging behavior. Firm stakeholders expect that appointees to important positions, such as risk managers, use their authority to improve the organization. According to traditional financial theory, risk managers should aim to reduce volatility, stabilize cash flows, and reduce the probability of financial distress (see, e.g.,Stulz, 1996; Mian, 1996; Stulz, 2013). As such, the goal of hedging is not to make money but to protect from losses. However, the literature provides ample evidence that risk managers instead engage in selective hedging activities (Adam \& Fernando, 2006), thereby creating additional risk exposures and subjecting firms to new risks (Adam et al., 2017). Selective hedging might lead to severe losses for the firm and, consequently, constitutes a potential dimension of ethical misconduct by management (Jones, 1991).

Our results have important implications for theory and practice, given that various conclusions for public policy and corporate governance, corporate risk management research, education, and theory testing can be drawn from the analysis.

For corporate practice, our analysis shows that specific personality traits might negatively affect financial risk management approaches. Managers with dark personalities might be particularly prone to selective hedging behaviors. This could have implications for human resources departments to carefully consider dark triad personality traits when hiring risk managers. Management assessment tests might need to explicitly consider such personality traits. Firms might also want to place more weight on risk managers' experience because these factors mitigate the impact of dark personality traits on unhealthy financial risk management decisions.

In addition, public and corporate policies promoting explicit corporate hedging activities could be expected to mitigate the impact of managers' dark personality traits on corporate risk management. Creating an environment within the risk management function that does not focus on the profitability of the hedging decisions but, rather, uses a risk-related measure to quantify success might be helpful. Particularly useful might also be to identify whether risk managers perceive generating additional profits as an important success criterion for financial risk management. Risk managers who focus on profitability rather than risk measures should not be put in charge of the firm's risk management function. This provides human resources departments with a more practical approach that does not rely on personality assessments. Considering the criticism of these assessments (Caponecchia et al., 2012), this approach might be particularly valuable.

From a research perspective, our study provides evidence that future research on educating risk managers should investigate how personality traits relate to risk management competencies. Although significant research has been conducted on competencies for risk managers, links to personality traits are to date missing in this literature. Can personality traits, which help to support corporate risk management, be identified with specific educational formats? Moreover, how can personality traits be considered when assessing candidates for risk management positions?

Despite the contribution to the literature and important practical implications, our study has some caveats. Although the survey methodology allows us to ask important questions, it has limits. Discussing causation is not possible. A common concern in survey-based research is that the results are affected by endogeneity issues. However, considering that individual differences in personality traits are essentially fixed by age 30 (McCrae \& Costa, 1994), before (most) risk managers are in the position to decide on their firms' hedging decisions, we are cautiously confident that reverse causality is not an issue in our setting. However, individuals with pronounced dark personality traits might actively pursue careers as risk managers to satisfy their thirst for risk and excitement. Such self-selection makes it particularly likely to find individuals with dark personality traits in risk manager positions, given the larger pool of applicants for these positions with said personality traits. However, it would not invalidate the association between dark personality traits and selective hedging. Another potential drawback is that surveys measure beliefs and preferences and not necessarily actions (Graham et al., 2013). However, considering that we specifically target risk managers with decision-making authority, we believe that a respondent who considers objectives such as "trading for profit" important for their hedging decisions not only has a preference to engage in selective hedging activities but can act on this preference. Thus, we are cautiously confident that the manager's preferences also characterize the company's hedging policy. Lastly, some of the questions might be misunderstood or produce only noisy measures of the variable in question. However, because it is difficult to obtain managers' personality traits and their propensity to engage in selective hedging at the same time through another research method, we nonetheless believe that our paper makes an important contribution. We also take great care and use best practices to mitigate the well-known pitfalls of surveys. Importantly, our results are in line with the previous literature on the prevalence of selective hedging activities (see, e.g.,Adam \& Fernando, 2006) and established determinants 
of selective hedging, such as (over)confidence (Adam et al., 2015) or risk preferences (Pennings \& Garcia, 2004).

Keeping these concerns in mind, our research design offers new and unique insights into the relationship between managers' personality characteristics and risk management competence, particularly selective hedging. These findings nicely complement recent studies on the determinants of selective hedging that use archival data (Adam et al., 2015; Bajo et al., 2021).

This study is a first step in evaluating the impact of dark personality traits on financial risk management activities in organizations. Future research should shed additional light on the mitigating factors that might help keep risk managers' dark personality traits at bay and, thereby, improve corporate risk management outcomes. Future research might want to study the degree to which the size of selective hedging positions varies with risk managers' personality traits. In particular, we expect that risk managers with more pronounced dark personality traits are not only more willing to engage in selective hedging but also are more willing to take larger positions based on their views.

\section{Appendix: Additional Analyses}

See Tables 9, 10, and 11.

Table 9 Variable definitions

\begin{tabular}{|c|c|}
\hline Variable & Definition \\
\hline \multicolumn{2}{|l|}{ Dependent variables } \\
\hline Selective hedging & Composite scale ranging from 1 to 5 measuring the selective hedging activities of risk managers \\
\hline Trade for profit & $\begin{array}{l}\text { Scale ranging from } 1 \text { to } 11 \text { measuring the degree to which risk managers attempt to make additional profit with their } \\
\text { hedges rather than manage the volatility of earnings and cash flows }\end{array}$ \\
\hline Market view & $\begin{array}{l}\text { Composite scale ranging from } 1 \text { to } 5 \text { measuring the degree to which a risk manager's market view influences their } \\
\text { hedging decisions }\end{array}$ \\
\hline \multicolumn{2}{|c|}{ Independent variables: personality traits } \\
\hline Dark triad & $\begin{array}{l}\text { Composite scale ranging from } 1 \text { to } 5 \text { measuring managerial personality traits (Machiavellianism, narcissism, and } \\
\text { psychopathy) based on Jonason and Webster (2010) }\end{array}$ \\
\hline Machiavellianism & Scale ranging from 1 to 5 measuring Machiavellianism based on Jonason and Webster (2010) \\
\hline Narcissism & Scale ranging from 1-5 measuring narcissism based on Jonason and Webster (2010) \\
\hline Psychopathy & Scale ranging from 1 to 5 measuring psychopathy based on Jonason and Webster (2010) \\
\hline \multicolumn{2}{|l|}{ Control variables } \\
\hline Risk preference & 11-level scale measuring managerial risk attitude based on Dohmen et al. (2011) \\
\hline Confidence & 11-level scale measuring risk managers' confidence in their hedging activities based on Weber and Brewer (2003) \\
\hline Male & Dummy variable that takes the value of one for male risk managers and zero otherwise \\
\hline Age & 6-level scale measuring risk managers' age \\
\hline Education & 6-level scale measuring risk managers’ education \\
\hline Derivatives expertise & 5-level scale measuring risk managers’ experience using derivatives \\
\hline Experience / tenure & 5-level scale measuring the risk manager's tenure with the firm \\
\hline Tail outcomes & $\begin{array}{l}\text { Composite scale ranging from } 1 \text { to } 5 \text { measuring the degree to which risk managers use hedging to eliminate lower- } \\
\text { tail outcomes }\end{array}$ \\
\hline Success $=$ profitability & $\begin{array}{l}\text { Dummy variable that takes the value of one for risk managers who perceive additional financial gains to be an } \\
\text { important success criterion of risk management activities and zero otherwise }\end{array}$ \\
\hline Professional position & $\begin{array}{l}\text { Dummy variable that takes the value of one if the risk manager is the director/manager corporate risk management } \\
\text { and zero otherwise }\end{array}$ \\
\hline Performance measurement & $\begin{array}{l}\text { Scale ranging from } 1 \text { to } 5 \text { measuring the degree to which a risk manager's performance is evaluated based on his or } \\
\text { her absolute profit/loss }\end{array}$ \\
\hline Reporting frequency & Scale ranging from 1 to 6 measuring the reporting frequency on a risk manager's hedging activities \\
\hline Centralization & Scale ranging from 1 to 11 measuring the degree to which firms' hedging activities are centralized \\
\hline Guidelines & $\begin{array}{l}\text { Scale ranging from } 0 \text { to } 5 \text { measuring the degree to which risk managers' hedging decisions are bound by internal } \\
\text { guidelines }\end{array}$ \\
\hline No. employees & 8-level variable indicating the number of employees in the respondent's firm \\
\hline Sales revenue & 8-level variable indicating the annual sales of the respondent's firm \\
\hline Private firm & Dummy variable that takes the value of one for non-family firms and zero otherwise \\
\hline Family firm & Dummy variable that takes the value of one for family firms and zero otherwise \\
\hline Government firm & Dummy variable that takes the value of one for government firms and zero otherwise \\
\hline
\end{tabular}


Table 10 Robustness: Dark personality traits and selective hedging

Dependent variables
Selective hedging

(1)

Machiavellianism

Controls

Industry effects

Country effects

Observations

Adjusted $R^{2}$

Residual SE

F Statistic
$0.0267 *$

(1.9308)

Yes

Yes

Yes

412

0.6234

0.3488

$22.2647 * * *$
Trade for profit

(2)

$0.2469 * * *$

(3.8056)

Yes

Yes

Yes

412

0.4190

1.5892

$10.2612 * * *$
Market view

(3)

$0.0521 * * *$

(2.7306)

Yes

Yes

Yes

412

0.4871

0.4934

$13.1981 * * *$

(4)

(5)

(6)

Narcissism

$0.0414 * *$

$0.2063 * *$

$0.0810 * * *$

(2.2027)

Controls

Yes

Industry effects

Yes

Yes

412

(2.3444)

(2.8887)

Country effects

Observations

0.6251

Yes

Yes

Yes

Yes

Yes

Yes

Yes

412

0.4075

412

Adjusted $R^{2}$

0.3481

1.6048

0.4914

Residual SE

$22.4144 * * *$

$9.8319 * * *$

0.4913

F Statistic

(7)

(8)

13.4114***

Psychopathy

0.0249
$(1.5433)$

$0.2831 * * *$

(9)

\section{Controls}

Industry effects

Yes

(3.5247)

$0.0553 * *$

Country effects

Yes

Yes

(2.5032)

Observations

Yes

412

Adjusted $R^{2}$

0.6225

0.3493

Yes

Yes

Yes

Yes

Yes

412

412

Residual SE

$22.1791 * * *$

0.4203

0.4864

0.4937

$10.3130 * * *$

$13.1632 * * *$

Regression coefficients are presented with $t$-values in parentheses and robust standard errors (MacKinnon and White 1985). ${ }^{*} p<0.1$;

$* * p<0.05 ; * * * p<0.01$. Variable definitions can be found in Table 9 in the Appendix 
Table 11 The non-finance sector, dark triad personality, and selective hedging

\begin{tabular}{llll}
\hline \multicolumn{4}{l}{ Dependent variable } \\
\cline { 2 - 4 } & Selective hedging & Trade for Profit & Market view \\
& $(1)$ & $(2)$ & $(3)$ \\
\hline Dark triad & $0.0613^{* *}$ & $0.3751^{* * *}$ & $0.0802^{*}$ \\
& $(2.0282)$ & $(2.8104)$ & $(1.7569)$ \\
Controls & Yes & Yes & Yes \\
Industry effects & Yes & Yes & Yes \\
Country effects & Yes & Yes & Yes \\
Observations & 188 & 188 & 188 \\
Adjusted $R^{2}$ & 0.6160 & 0.4161 & 0.5021 \\
Residual SE & 0.3371 & 1.5629 & $0.4847 * * *$ \\
F Statistic & $10.6765^{* * *}$ & $5.2992^{* * *}$ & 7.0828 \\
\hline
\end{tabular}

Regression coefficients are presented with $t$-values in parentheses and robust standard errors (MacKinnon and White 1985). ${ }^{*} p<0.1$; ${ }^{* *}$ $p<0.05$; $^{* * *} p<0.01$. Variable definitions can be found in Table 9 in the Appendix

Acknowledgements Author order is the result of randomization. We are grateful for the helpful comments and suggestions from Greg Shailer (the editor), two anonymous referees, Stylianos Asimakopoulos (discussant), Christina Bannier (discussant), Brad Cannon (discussant), Ernst Eichenseher (discussant), Ahmed Ameya Prapan (discussant), Philipp Roßmann (discussant), André Uhde, Louis Williams (discussant), participants of the 37th International Conference of the French Finance Association (AFFI), the 2021 Behavioral Finance Working Group Conference, the Frankfurter Institut für Risikomanagement und Regulierung (FIRM) research conference, the European Financial Management Association 2021 Annual Meeting, the 2021 Annual Meeting of Academies of Behavioral Finance \& Economics, the 2021 International Risk Management Conference, the 27th Annual Meeting of the German Finance Association (DGF), and seminar participants at Paderborn University, ESCP Berlin, and Hamburg University. We gratefully acknowledge financial support from the Frankfurter Institut für Risikomanagement und Regulierung (FIRM). We thank Minh-Lý Liêu and Lara Stehl for outstanding research support. Any errors, misrepresentations, and omissions are our own. The data are available at https://doi.org/10.17632/dw4frpsknz.1.

Funding Open Access funding enabled and organized by Projekt DEAL. We gratefully acknowledge financial support from the Frankfurter Institut für Risikomanagement und Regulierung (FIRM).

\section{Declarations}

Conflict of interest All authors declare they have no conflicts of interest.

Ethical Approval The procedures performed involving human participants were in accordance with the ethical standards of the 1964 Helsinki declaration and its later amendments or comparable ethical standards. Every precaution was taken to protect the privacy of research subjects and the confidentiality of their personal information. The study was reviewed and approved by the institutional ethics review board of Paderborn University (2020-08-12).
Informed Consent Informed consent was obtained from all individual participants included in the study. Participation by individuals was voluntary, and all participants could terminate the study at any time without negative consequences.

Open Access This article is licensed under a Creative Commons Attribution 4.0 International License, which permits use, sharing, adaptation, distribution and reproduction in any medium or format, as long as you give appropriate credit to the original author(s) and the source, provide a link to the Creative Commons licence, and indicate if changes were made. The images or other third party material in this article are included in the article's Creative Commons licence, unless indicated otherwise in a credit line to the material. If material is not included in the article's Creative Commons licence and your intended use is not permitted by statutory regulation or exceeds the permitted use, you will need to obtain permission directly from the copyright holder. To view a copy of this licence, visit http://creativecommons.org/licenses/by/4.0/.

\section{References}

Aabo, T., Andryeyeva Hansen, M., \& Pantzalis, C. (2012). Corporate foreign exchange speculation and integrated risk management. Managerial Finance, 38, 729-751.

Adam, T. R., \& Fernando, C. S. (2006). Hedging, speculation, and shareholder value. Journal of Financial Economics, 81, 283-309.

Adam, T. R., Fernando, C. S., \& Golubeva, E. (2015). Managerial overconfidence and corporate risk management. Journal of Banking \& Finance, 60, 195-208.

Adam, T. R., Fernando, C. S., \& Salas, J. M. (2017). Why do firms engage in selective hedging? Evidence from the gold mining industry. Journal of Banking \& Finance, 77, 269-282.

Aktas, N., de Bodt, E., Bollaert, H., \& Roll, R. (2016). CEO Narcissism and the takeover process: From private initiation to deal completion. Journal of Financial and Quantitative Analysis, 51, 113-137.

Babiak, P., \& Hare, R. D. (2006). Snakes in suits: When psychopaths go to work. Regan Books.

Babiak, P., Neumann, C. S., \& Hare, R. D. (2010). Corporate psychopathy: Talking the walk. Behavioral Sciences \& the Law, $28,174-193$.

Bajo, E., Jankensgård, H., \& Marinelli, N. (2021). "Me, myself and I: CEO Narcissism and Selective Hedging," European Financial Management, (in press).

Balogun, J., \& Johnson, G. (2004). Organizational restructuring and middle manager sensemaking. The Academy of Management Journal, 47, 523-549.

Barach, J. A., \& Ganitsky, J. B. (1995). Successful succession in family business. Family Business Review, 8, 131-155.

Beber, A., \& Fabbri, D. (2012). Who times the foreign exchange market? Corporate speculation and CEO characteristics. Journal of Corporate Finance, 18, 1065-1087.

Bergman, A., Chinco, A., \& Sussman, S. M. H. A. B. (2020). Survey Curious? Start-up guide and best practices for running surveys and experiments online. Working Paper.

Berson, Y., Oreg, S., \& Dvir, T. (2008). CEO values, organizational culture and firm outcomes. Journal of Organizational Behavior, $29,615-633$.

Bertrand, M., \& Schoar, A. (2003). Managing with style: the effect of managers on firm policies. The Quarterly Journal of Economics, 118, 1169-1208.

Biguri, K., Brownlees, C., \& Ippolito, F. (2018). Corporate hedging and the variance of stock returns. Working Paper. 
Boddy, C. R. (2017). Psychopathic leadership: A case study of a corporate psychopath CEO. Journal of Business Ethics, 145, 141-156.

Bodnar, G. M., Hayt, G. S., \& Marston, R. C. (1998). 1998 Wharton Survey of financial risk management by US Non-Financial Firms. Financial Management, 27, 70-91.

Brown, G. W., Crabb, P. R., \& Haushalter, D. (2006). Are firms successful at selective hedging? The Journal of Business, 79, 2925-2949.

Campbell, W. K., Goodie, A. S., \& Foster, J. D. (2004). Narcissism, confidence, and risk attitude. Journal of Behavioral Decision Making, 17, 297-311.

Campello, M., Lin, C., Ma, Y., \& Zou, H. (2011). The real and financial implications of corporate hedging. The Journal of Finance, 66 , $1615-1647$.

Caponecchia, C., Sun, A. Y. Z., \& Wyatt, A. (2012). Psychopaths' at Work? Implications of lay persons' use of labels and behavioural criteria for psychopathy. Journal of Business Ethics, 107, 399-408.

Carey, A. L., Brucks, M. S., Küfner, A. C. P., Holtzman, N. S., \& große Deters, F., Back, M. D., Donnellan, M. B., Pennebaker, J. W., \& Mehl, M.R. (2015). Narcissism and the use of personal pronouns revisited. Journal of Personality and Social Psychology, 109, e1-e15.

Carter, D. A., Rogers, D. A., \& Simkins, B. J. (2006). Hedging and Value in the U.S. Airline Industry. Journal of Applied Corporate Finance, 18, 21-33.

Chang, S.-J., van Witteloostuijn, A., \& Eden, L. (2010). From the Editors: Common method variance in international business research. Journal of International Business Studies, 41, 178-184.

Chatterjee, A., \& Hambrick, D. C. (2007). It's All about Me: Narcissistic Chief Executive Officers and their effects on company strategy and performance. Administrative Science Quarterly, 52, 351-386.

Chatterjee, A., \& Hambrick, D. C. (2011). Executive personality, capability cues, and risk taking: How Narcissistic CEOs react to their successes and stumbles. Administrative Science Quarterly, 56, 202-237.

Chatterjee, A., \& Pollock, T. G. (2017). Master of puppets: How Narcissistic CEOs construct their professional worlds. Academy of Management Review, 42, 703-725.

Cragun, O. R., Olsen, K. J., \& Wright, P. M. (2020). Making CEO Narcissism research great: A review and meta-analysis of CEO Narcissism. Journal of Management, 46, 908-936.

Croci, E., del Giudice, A., \& Jankensgård, H. (2017). CEO age, risk incentives, and hedging strategy. Financial Management, 46, 687-716.

Crysel, L. C., Crosier, B. S., \& Webster, G. D. (2013). The Dark Triad and risk behavior. Personality and Individual Differences, 54, $35-40$.

Dohmen, T., Falk, A., Huffman, D., Sunde, U., Schupp, J., \& Wagner, G. G. (2011). Individual risk attitudes: Measurement, determinants, and behavioral consequences. Journal of the European Economic Association, 9, 522-550.

Durant, L. E., Carey, M. P., \& Schroder, K. E. E. (2002). Effects of anonymity, gender, and erotophilia on the quality of data obtained from self-reports of socially sensitive behaviors. Journal of Behavioral Medicine, 25, 439-467.

Emmons, R. A. (1981). Relationship between narcissism and sensation seeking. Psychological Reports, 48, 247-250.

Falkner, E. M., \& Hiebl, M. R. (2015). Risk management in SMEs: A systematic review of available evidence. The Journal of Risk Finance, 16, 122-144.

Faulkender, M. (2005). Hedging or market timing? Selecting the interest rate exposure of corporate debt. The Journal of Finance, 60, 931-962.
Feng, L., \& Seasholes, M. (2005). Do investor sophistication and trading experience eliminate behavioral biases in financial markets? Review of Finance, 9, 305-351.

Finkelstein, S., \& Boyd, B. K. (1998). How much does the CEO matter? The role of managerial discretion in the setting of CEO compensation. The Academy of Management Journal, 41, 179-199.

Finkelstein, S., \& Hambrick, D. C. (1990). Top-management-team tenure and organizational outcomes: The moderating role of managerial discretion. Administrative Science Quarterly, 35, 484-503.

Fowler, Jr., F. J. (2013). Survey research methods, 5th Ed. Sage.

Froot, K. A., Scharfstein, D. S., \& Stein, J. C. (1993). Risk management: Coordinating corporate investment and financing policies. The Journal of Finance, 48, 1629-1658.

Furtner, M. R., Maran, T., \& Rauthmann, J. F. (2017). Dark leadership: The role of leaders' Dark Triad personality traits. In M. G. Clark \& C. W. Gruber (Eds.), Leader Development Deconstructed (pp. 75-99). Springer.

Gabriel, M. T., Critelli, J. W., \& Ee, J. S. (1994). Narcissistic illusions in self-evaluations of intelligence and attractiveness. Journal of Personality, 62, 143-155.

Geyer-Klingeberg, J., Hang, M., \& Rathgeber, A. (2020). Corporate Financial hedging and firm value: A meta-analysis. SSRN Working Paper.

Graham, J. R., \& Harvey, C. R. (2001). The theory and practice of corporate finance: Evidence from the field. Journal of Financial Economics, 60, 187-243.

Graham, J. R., Harvey, C. R., \& Puri, M. (2013). Managerial attitudes and corporate actions. Journal of Financial Economics, 109, 103-121.

Gunnthorsdottir, A., McCabe, K., \& Smith, V. (2002). Using the Machiavellianism instrument to predict trustworthiness in a bargaining game. Journal of Economic Psychology, 23, 49-66.

Halek, M., \& Eisenhauer, J. G. (2001). Demography of risk aversion. The Journal of Risk and Insurance, 68, 1-24.

Hambrick, D. C. (2007). Upper Echelons theory: An update. The Academy of Management Review, 32, 334-343.

Hambrick, D. C., \& Mason, P. A. (1984). Upper Echelons: The organization as a reflection of its top managers. The Academy of Management Review, 9, 193-206.

Hare, R. D. (1999). Without conscience: The disturbing world of the psychopaths among us. The Guilford Press.

Harman, H. H. (1976). Modern factor analysis. University of Chicago Press.

Harris, L., Jackson, S., Owens, J., \& Seybert, N. (2021) Recruiting Dark personalities for earnings management. Journal of Business Ethics, (in press).

Harrison, A., Summers, J., \& Mennecke, B. (2018). The effects of the Dark Triad on unethical behavior. Journal of Business Ethics, 153, 53-77.

Haushalter, G. D. (2000). Financing policy, basis risk, and corporate hedging: Evidence from oil and gas producers. The Journal of Finance, 55, 107-152.

He, X., Inman, J. J., \& Mittal, V. (2008). Gender jeopardy in financial risk taking. Journal of Marketing Research, 45, 414-424.

Hobson, J., \& Resutek, R. (2008). More than money: The effects of social status and Narcissism on manager reporting behavior. SSRN Electronic Journal.

Ipsen, E. (1993). Shell Gains Despite Currency Fiasco. The New York Times, Issue Feb. 23 (1993).

Jankensgård, H. (2019). Does managerial power increase selective hedging? Evidence from the oil and gas industry. Journal of Risk and Financial Management, 12, 1-18.

Jonason, P. K., \& Webster, G. (2010). The dirty dozen: A concise measure of the Dark Triad. Psychological Assessment, 22, 420-432. 
Jones, D. N. (2014). Risk in the face of retribution: Psychopathic individuals persist in financial misbehavior among the Dark Triad. Personality and Individual Differences, 67, 109-113.

Jones, T. M. (1991). Ethical decision making by individuals in organizations: An issue-contingent model. The Academy of Management Review, 16, 366-395.

Kets de Vries, M. (2004). Organizations on the couch: A clinical perspective on organizational dynamics. European Management Journal, 22, 183-200.

Kung, F. Y., Kwok, N., \& Brown, D. J. (2018). Are attention check questions a threat to scale validity? Applied Psychology, 67, 264-283.

LeBreton, J. M., Shiverdecker, L. K., \& Grimaldi, E. M. (2018). The Dark Triad and workplace behavior. Annual Review of Organizational Psychology and Organizational Behavior, 5, 387-414.

Li, J., \& Tang, Y. (2010). CEO Hubris and firm risk taking in China: The moderating role of managerial discretion. Academy of Management Journal, 53, 45-68.

Libby, R., Bloomfield, R., \& Nelson, M. W. (2002). Experimental research in financial accounting. Accounting, Organizations and Society, 27, 775-810.

Liu, Y., Chen, S., Bell, C., \& Tan, J. (2020). How do power and status differ in predicting unethical decisions? A cross-national comparison of China and Canada. Journal of Business Ethics, 167, 745-760.

MacKinnon, J. G., \& White, H. (1985). Some heteroskedasticity-consistent covariance matrix estimators with improved finite sample properties. Journal of Econometrics, 29, 305-325.

McCrae, R. R., \& Costa, P. T. (1994). The stability of personality: Observations and evaluations. Current Directions in Psychological Science, 3, 173-175.

Menon, M. K., \& Sharland, A. (2011). Narcissism, exploitative attitudes, and academic dishonesty: An exploratory investigation of reality versus myth. Journal of Education for Business, 86, $50-55$.

Mian, S. L. (1996). Evidence on corporate hedging policy. Journal of Financial and Quantitative Analysis, 31, 419-439.

Moore, J., Culver, J., \& Masterman, B. (2000). Risk management for middle market companies. Journal of Applied Corporate Finance, 12, 112-119.

Murphy, P. R. (2012). Attitude, Machiavellianism and the rationalization of misreporting. Accounting, Organizations and Society, 37, 242-259.

Mutschmann, M., Hasso, T., \& Pelster, M. (2021). Dark Triad managerial personality and financial reporting manipulation. Journal of Business Ethics, (in press).

Neo, B., Sellbom, M., Smith, S. F., \& Lilienfeld, S. O. (2018). Of boldness and badness: Insights into workplace Malfeasance from a triarchic psychopathy model perspective. Journal of Business Ethics, 149, 187-205.

Omar, A. M. A., Wisniewski, T. P., \& Yekini, L. S. (2019). Psychopathic traits of corporate leadership as predictors of future stock returns. European Financial Management, 25, 1196-1228.

Parks-Leduc, L., Feldman, G., \& Bardi, A. (2015). Personality traits and personal values: A meta-analysis. Personality and Social Psychology Review, 19, 3-29.

Patrick, C. J. (2007). Personality disorders: Toward the DSM-V. In Antisocial personality disorder and psychopathy (pp. 109-166). SAGE.

Paulhus, D. L., \& Jones, D. N. (2015). Measures of dark personalities. In G. J. Boyle, D. H. Saklofske, \& G. Matthews (Eds.), Measures of personality and social psychological constructs (pp. 562-594). Academic Press.

Paulhus, D. L., \& Williams, K. M. (2002). The Dark Triad of personality: Narcissism, Machiavellianism, and psychopathy. Journal of Research in Personality, 36, 556-563.
Pearlin, L. I. (1961). The appeals of anonymity in Questionnaire Response. The Public Opinion Quarterly, 25, 640-647.

Pelster, M., \& Schaltegger, S. (2021). The Dark Triad and corporate sustainability: An empirical analysis of personality traits of sustainability managers. Business Ethics, the Environment \& Responsibility, (forthcoming).

Pennings, J. M., \& Garcia, P. (2004). Hedging behavior in small and medium-sized enterprises: The role of unobserved heterogeneity. Journal of Banking \& Finance, 28, 951-978.

Petrenko, O. V., Aime, F., Ridge, J., \& Hill, A. (2016). Corporate social responsibility or CEO narcissism? CSR motivations and organizational performance. Strategic Management Journal, 37, $262-279$.

Phillips, A. L. (1995). 1995 Derivatives practices and instruments survey. Financial Management, 24, 115-125.

Podsakoff, P. M., MacKenzie, S. B., Lee, J.-Y., \& Podsakoff, N. P. (2003). Common method biases in behavioral research: A critical review of the literature and recommended remedies. Journal of Applied Psychology, 88, 879-903.

Rijsenbilt, A., \& Commandeur, H. (2013). Narcissus enters the courtroom: CEO Narcissism and fraud. Journal of Business Ethics, 117, 413-429.

Rim, Y. (1966). Machiavellianism and decisions involving risk. British Journal of Social and Clinical Psychology, 5, 30-36.

Rovelli, P., \& Curnis, C. (2020). The perks of narcissism: Behaving like a star speeds up career advancement to the CEO position. The Leadership Quarterly, 101489.

Sekścińska, K., \& Rudzinska-Wojciechowska, J. (2020). Individual differences in Dark Triad Traits and risky financial choices. Personality and Individual Differences, 152, 109598.

Sharma, S. (2000). Managerial interpretations and organizational context as predictors of corporate choice of environmental strategy. Academy of Management Journal, 43, 681-697.

Shefrin, H. (2016). Behavioral risk management. Palgrave Macmillan.

Stevens, G. W., Deuling, J. K., \& Armenakis, A. A. (2012). Successful psychopaths: Are they unethical decision-makers and why? Journal of Business Ethics, 105, 139-149.

Stulz, R. M. (1996). Rethinking risk management. Journal of Applied Corporate Finance, 9, 8-25.

Stulz, R. M. (2013). How companies can use hedging to create shareholder value. Journal of Applied Corporate Finance, 25, 21-29.

ten Brinke, L., Kish, A., \& Keltner, D. (2018). Hedge fund managers with psychopathic tendencies make for worse investors. Personality and Social Psychology Bulletin, 44, 214-223.

Tufano, P. (1996). Who manages risk? An empirical examination of risk management practices in the gold mining industry. The Journal of Finance, 51, 1097-1137.

Vazire, S., \& Funder, D. C. (2006). Impulsivity and the self-defeating behavior of Narcissists. Personality and Social Psychology Review, 10, 154-165.

Vogel, C. (2006). A field guide to narcissism. Psychology Today, 39, $68-74$.

Weber, N., \& Brewer, N. (2003). The effect of judgment type and confidence scale on confidence-accurary calibration in face recognition. Journal of Applied Psychology, 88, 490-499.

Webster, G. D., \& Jonason, P. K. (2013). Putting the "IRT" in "Dirty": Item response theory analyses of the Dark Triad Dirty Dozen: An efficient measure of narcissism, psychopathy, and Machiavellianism. Personality and Individual Differences, 54, 302-306.

Williams, K. M., Paulhus, D. L., \& Hare, R. D. (2007). Capturing the four-factor structure of psychopathy in college students via selfreport. Journal of Personality Assessment, 88, 205-219.

Wink, P., \& Donahue, K. (1997). The relation between two types of Narcissism and Boredom. Journal of Research in Personality, 31, 136-140. 
Wooldridge, B., Schmid, T., \& Floyd, S. W. (2008). The middle management perspective on strategy process: Contributions, synthesis, and future research. Journal of Management, 34, 1190-1221.

Zuckerman, M. (1979). Sensation seeking and risk taking. In C. E. Izard (Ed.), Emotions in personality and psychopathology (pp. 161-197). Springer.
Publisher's Note Springer Nature remains neutral with regard to jurisdictional claims in published maps and institutional affiliations. 